\title{
Dynamics and style transition of a moderate, Vulcanian-driven eruption at Tungurahua (Ecuador) in February 2014: pyroclastic deposits and hazard considerations
}

\author{
Jorge Eduardo Romero ${ }^{1}$, Guilhem Amin Douillet ${ }^{2}$, Silvia Vallejo Vargas ${ }^{3}$, Jorge Bustillos ${ }^{4}$, Liliana Troncoso ${ }^{4}$, \\ Juan Díaz Alvarado ${ }^{1}$, and Patricio Ramón ${ }^{3}$ \\ ${ }^{1}$ Departamento de Geología, Universidad de Atacama, Copiapó, Chile \\ ${ }^{2}$ Earth and Environmental Sciences, Ludwig-Maximilians-Universität, Munich, Germany \\ ${ }^{3}$ Instituto Geofísico, Escuela Politécnica Nacional, Quito, Ecuador \\ ${ }^{4}$ Escuela de Geología, Facultad de Geología, Minas, Petróleos y Ambiental (FIGEMPA), \\ Universidad Central del Ecuador, Quito, Ecuador
}

Correspondence to: Guilhem Amin Douillet (g.douillet@min.uni-muenchen.de)

Received: 21 November 2016 - Discussion started: 14 December 2016

Revised: 1 May 2017 - Accepted: 15 May 2017 - Published: 23 June 2017

\begin{abstract}
The ongoing eruptive cycle of Tungurahua volcano (Ecuador) since 1999 has been characterised by over 15 paroxysmal phases interrupted by periods of relative calm. Those phases included one Subplinian as well as several Strombolian and Vulcanian eruptions and they generated tephra fallouts, pyroclastic density currents (PDCs) and lava flows. The 1 February 2014 eruption occurred after 75 days of quiescence and only 2 days of pre-eruptive seismic crisis. Two short-lived Vulcanian explosions marked the onset of the paroxysmal phase, characterised by a $13.4 \mathrm{~km}$ eruptive column and the trigger of PDCs. After 40 min of paroxysm, the activity evolved into sporadic Strombolian explosions with discrete ash emissions and continued for several weeks.

Both tephra fall and PDCs were studied for their dispersal, sedimentology, volume and eruption source parameters. At large scale, the tephra cloud dispersed toward the SSW. Based on the field data, two dispersal scenarios were developed forming either elliptical isopachs or proximally PDCinfluenced isopachs. The minimum bulk tephra volumes are estimated to $4.55 \times 10^{6} \mathrm{~m}^{3}$, for an eruption size estimated at volcanic explosivity index (VEI) 2-3. PDCs, although of small volume, descended by nine ravines of the NNW flanks down to the base of the edifice. The 1 February 2014 eruptions show a similar size to the late 1999 and August 2001 events, but with a higher intensity (I 9-10) and shorter dura-
\end{abstract}

tion. The Vulcanian eruptive mechanism is interpreted to be related to a steady magma ascent and the rise in over-pressure in a blocked conduit (plug) and/or a depressurised solidification front. The transition to Strombolian style is well documented from the tephra fall componentry. In any of the interpretative scenarios, the short-lived precursors for such a major event as well as the unusual tephra dispersion pattern urge for renewed hazard considerations at Tungurahua.

\section{Introduction}

In comparison to Strombolian or Plinian fallout deposits, Vulcanian fine-grained fallout deposits often lack a sufficient preservation potential for extensive studies from proximal to distal portions (Rose et al., 2008). Generally, these eruptions produce predominantly fine-ash to lapilli-sized tephra which is dispersed to heights $<20 \mathrm{~km}$ and last on the order of minutes (Morrissey and Mastin, 2000). Vulcanian events commonly originate from andesitic or dacitic magma composition (e.g. Cas and Wright, 1987; Cole et al., 2015; Hall et al., 2015; Zobin et al., 2016). Typically, the juvenile ejected material is dominated by block to fine-ash-sized tephra with poor to moderate vesicularity, angular shape and vitric to crystalline texture (Morrissey and Mastin, 2000). Non-juvenile rocks make a major fraction of the ejected ma- 
terial. All those observation are interpreted to show the progressive deepening of the source in the magma conduit, brittle fragmentation of highly viscous magma and high explosivity (e.g. Clarke et al., 2015). The ejected tephra thus help to constrain the source depth and intensity of the eruption. Vulcanian eruptions can be associated with the generation of pyroclastic density currents (PDCs; e.g. Brown and Andrews, 2015), especially if they trigger moderate andesitic eruptions, which are more prone to produce PDCs than other eruption types (Bernard et al., 2016). Although the transitional behaviours of Vulcanian eruptions from/to Subplinian and Strombolian eruptions are occasionally observed (Maeno et al., 2013), these changes in the eruptive style have not been widely described or claimed much attention, in particular for volcanic hazard assessment.

This study focuses on the pyroclastic deposits associated with the eruptions from 1 to 14 February 2014 of Tungurahua volcano (Ecuador). Tephra fallout and PDC erupted material are described and used to infer the style transition, eruption magnitude and source parameters. Special attention is given to explain the unusual rapid evolution from unrest to eruption, and the possible existence of a plug in the conduit. The deposits and flow of PDCs are also described and discussed. The meaning of this eruption is put in perspective with the context of Tungurahua's ongoing cycle.

\subsection{Historical activity of Tungurahua}

The Tungurahua stratovolcano $\left(01^{\circ} 28^{\prime} \mathrm{S}, \quad 78^{\circ} 27^{\prime} \mathrm{W}\right.$; 5019 ma.s.l.) is among the most active Ecuadorian volcanoes, with five post-Columbian eruptions (1641-1646, 1773-1781, 1886-1888, 1916-1918 and 1999-to-present; Hall et al., 1999; Le Pennec et al., 2008; Hall et al., 2013). The ongoing eruptive cycle (1999-present) has consisted of short periods of low to moderate Strombolian activity with lava fountaining, Vulcanian explosions, lava flows, and PDCs (Douillet et al., 2013b, a; Hall et al., 2013, 2015). Tephra fallout from these eruptions is constituted by mostly asymmetric isopachs distributed toward the west, controlled by the regional wind direction (Bustillos, 2010; Eychenne et al., 2012, 2013; Bernard et al., 2013; Bustillos et al., 2016).

The largest eruption of the cycle (up to present) occurred on 17 August 2006. It produced a plume that reached a height of $18 \mathrm{~km}$ (Eychenne et al., 2012) and PDCs which descended 17 valleys located around the summit (Kelfoun et al., 2009; Douillet et al., 2013b, a), as well as a'a lava flows on the upper flanks. The eruption affected for many years the villages of Cusúa, Chacauco, Bilbao and Juive-Grande as well as national roads around the volcano (Samaniego et al., 2008; Kelfoun et al., 2009; Hall et al., 2013). Prior to the eruptions of July and August 2006, deep (10-15 km depth) long-period (LP) seismicity and edifice inflation were registered from April to May 2006 (Champenois et al., 2014). PDCs have become more frequent since 2008, with occur- rence in 2008, 2010, 2011, 2012 and 2013, affecting livestock and agriculture on the flanks of the volcano. The character of eruptions has remarkably evolved from Strombolian to Vulcanian-dominated activity since 2010 and the frequency of eruptions has increased from 2006 up to present, doubling the tephra discharge rate (Bustillos et al., 2016, and references therein). Volcano degassing evolved from a moreor-less continuous activity between 1999 and late 2008 to episodic activity without significant degassing during quiescence periods (Arellano et al., 2008; Hidalgo et al., 2015). In mid-2013 and continuing until mid-2014, a cycle of Vulcanian explosions often associated with PDCs began, possibly linked to the plugging of the conduit (Hall et al., 2015). The eruption of 14 July 2013, occurred after 2 months of quiescence and weak degassing, producing a $8.8 \mathrm{~km}$ high eruption column accompanied by a series of PDCs descending in at least nine valleys of the flanks up to $7.5 \mathrm{~km}$ from the cone (Hall et al., 2015; Parra et al., 2016).

\subsection{The February 2014 eruption}

A precise description of the February 2014 eruption chronology is summarised hereafter from the reports of the Instituto Geofísico of the Escuela Politécnica Nacional from Quito (IG-EPN). It is based on the robust monitoring network of the Observatory of Volcano Tungurahua (OVT; http: //www.igepn.edu.ec). From 13 November 2013 to 29 January 2014, the volcano experienced 77 days without any eruptive activity apart for a weak background degassing. On 30 January 2014, a new eruptive phase begun with an increase in seismic activity and few sporadic explosions accompanied by tephra fallout distributed toward the SW (Instituto Geofísico, 2014a). After a reduction in seismicity on 31 January, the seismic activity increased again dramatically on 1 February between 01:10 and 20:30 UTC (Ecuadorian local time $+5 \mathrm{~h}$ ), with a swarm of volcano-tectonic (VT) and long-period (LP) events. At 17:00 UTC, the OVT reported to the Decentralised Government of Baños Risk Management Department (SGR, GAD-Baños) and through a public announcement concerning the evolving seismic activity and increased possibility of eruption. The first large explosion occurred at 22:12 UTC, producing a $5 \mathrm{~km}$ high column accompanied by PDCs that descended $0.5 \mathrm{~km}$ down the NW flank (Instituto Geofísico, 2014b). Another explosion at 22:32 UTC generated a new burst of PDCs with a similar distribution (Instituto Geofísico, 2014b). The third explosion at 22:39 UTC was the trigger of the major Vulcanian eruption and was associated with the largest PDCs (Instituto Geofísico, 2014c). These PDCs branched into at least nine ravines from the $\mathrm{N}, \mathrm{W}$ and SW flanks of the volcano down to the base of the edifice. Hall et al. (2015) estimated the PDC flow velocities at 9.5$36 \mathrm{~m} \mathrm{~s}^{-1}$. The paroxysm persisted for $42 \mathrm{~min}$, but the highest sustained eruption column of $13.7 \mathrm{~km}$ lasted only $9 \mathrm{~min}$ (http://www.ssd.noaa.gov/VAAC/messages.html). A second eruptive phase dominated by fountaining Strombolian activ- 
ity started at 23:36 UTC with ejection of incandescent bombs up to $0.8-1.0 \mathrm{~km}$ above the crater, shock waves (pressure waves?) and explosions felt up to $20-30 \mathrm{~km}$ from the crater (Instituto Geofísico, 2014d). The evacuation in Chacauco and Cusúa (W flank), as well as Bilbao and Juive-Grande (NNW flank), took place at 23:44 UTC. Tephra fallout up to lapilli grain sizes was reported in the localities of Pillate, Capil and Palictahua (6-7 km from the vent) and the eruption cloud resulted in total darkness at the village of Chacauco. A deflation of $340 \mu \mathrm{rad}$ was observed subsequently to the end of the eruption, and following the inflation trend that was observed since October 2013 at RETU tilt meter (Vallejo et al., 2014). After this main episode, the activity continued with sporadic Strombolian explosions and discrete emissions of material decreasing in frequency over the whole of February.

\section{Sampling and analytical methods}

\subsection{Analysis of the tephra clouds and their deposits}

The field surveys on the fallout deposit were carried out two weeks after the main explosion and thus contain the signature of two weeks of activity. The weather situation around the volcano was described as clear sky between 4 and 9 February, light rains from 7 February onwards reported around the volcano, with the summit not visible due to clouds on 10-11 February (a typical situation).

We selected 23 locations with plane surfaces covered by tephra fallout without apparent reworking in order to measure deposit thickness and describe the sedimentological characteristics of the two weeks of eruption. Tephra thicknesses were measured directly with a scale by cutting open the deposits. The result for each individual location is the average of five nearby measurements (Fig. A1).

For distal points reported from geo-referenced photographs were a continuous blanket of tephra was covering the surface, an arbitrary value of $0.1 \mathrm{~mm}$ thickness is taken, even if the exact value may be largely variable (e.g. Loja, $290 \mathrm{~km}$ south, Fig. A1).

Four samples were sieved manually in $0.5 \phi$ intervals: B1 and $\mathrm{C} 1$ from 1 to $4 \phi$; $\mathrm{C} 2$ and $\mathrm{SJ}$ from -2.0 to $4.0 \phi$, with $\phi=$ $-\log \left(2 D / D_{0}\right)\left(D\right.$ is the particle diameter and $\left.D_{0}=1 \mathrm{~mm}\right)$. The calculation of grain-size parameters (e.g. Otto, 1939; Inman, 1952; Folk and Ward, 1957; Cas and Wright, 1987; Murcia et al., 2013) was obtained with the Gradisat package (Blott and Pye, 2001).

Two tephra fall isopach maps representing two possible scenarios were hand-drawn based on the data points. Bulk tephra volumes were calculated by the integration of four or five isopachs (two straight-line segments) for each scenario using the models of exponential thinning (Pyle, 1989, 1995; Fierstein and Nathenson, 1992), power law (Bonadonna and Houghton, 2005) and Weibull (Bonadonna and Costa, 2012).
Wind directions tendencies at $15 \mathrm{~km}$ a.s.l. around Tungurahua were reconstructed statistically from 32140 wind data from the 1999-2011 period, including 7940 for the JanuaryMarch period, using the wind reanalysis code (Palma, 2013).

Geostationary Operational Environmental Satellite (GOES) 8 and 13 imagery, combined with the information of VAAC reports (http://www.ssd.noaa.gov/VAAC/ARCH14/ TUNG/), was used to describe the tephra dispersion during the eruption.

\subsection{Sampling and analysis of PDC deposits}

The PDC deposits were observed in the field between 8 and 25 February. Between 600 and $1200 \mathrm{~g}$ was sampled at 22 locations and the matrix (considered as the fraction $<2.8 \mathrm{~cm}$ ) was sieved mechanically in $0.5 \phi$ steps with a shaker from Retsch. The sieving protocol was 15 min shaking in intervals of $20 \mathrm{~s}$ steps with a brief pause between each step for the whole fraction. The fraction $<0.5 \mathrm{~mm}$ was additionally shaken for $5 \mathrm{~min}$ in $10 \mathrm{~s}$ intervals. This protocol was chosen to ensure the lowest amount of clast abrasion during sieving. Further, the fine fraction $(<0.125 \mathrm{~mm})$ was analysed with a laser-diffraction particle-size analyser (LS230 from Coulter) with each sample measured five times with three consecutive runs, and the final result was taken as the average of all runs. Particles' densities were considered homogeneous between the different grain sizes when calculating the median diameters and sorting parameters. This means that the volume (surface) fractions measured by laser diffraction were translated linearly into weight fractions in order to build composite grain-size curves with the mechanical results (measured in weight).

Ground temperature within the PDC deposits was measured between 8 and 14 February. Each site was measured at varying depths by digging and sinking a thermal probe in the ground and reading the temperature on a digital thermometer after stabilisation.

Major element bulk rock geochemistry was performed on three samples collected from fresh PDC deposits: a juvenile scoria and two fragments of a dense blocks. The analysis was carried out using a X-ray fluorescence (XRF) S8-Tiger (Bruker) and the software Spectraplus. The modal estimations of minerals were obtained by both a simple visual chart and ImageJ calculations.

\section{Data}

\subsection{Fallout deposits}

\subsubsection{Distribution and volume of tephra fallout deposits}

The tephra fallout field study was carried out in midFebruary and thus contains the signature of 2 weeks of activity (between 1 and 14 February). Two interpretative isopachs maps based on 22 data points are presented. They vary es- 

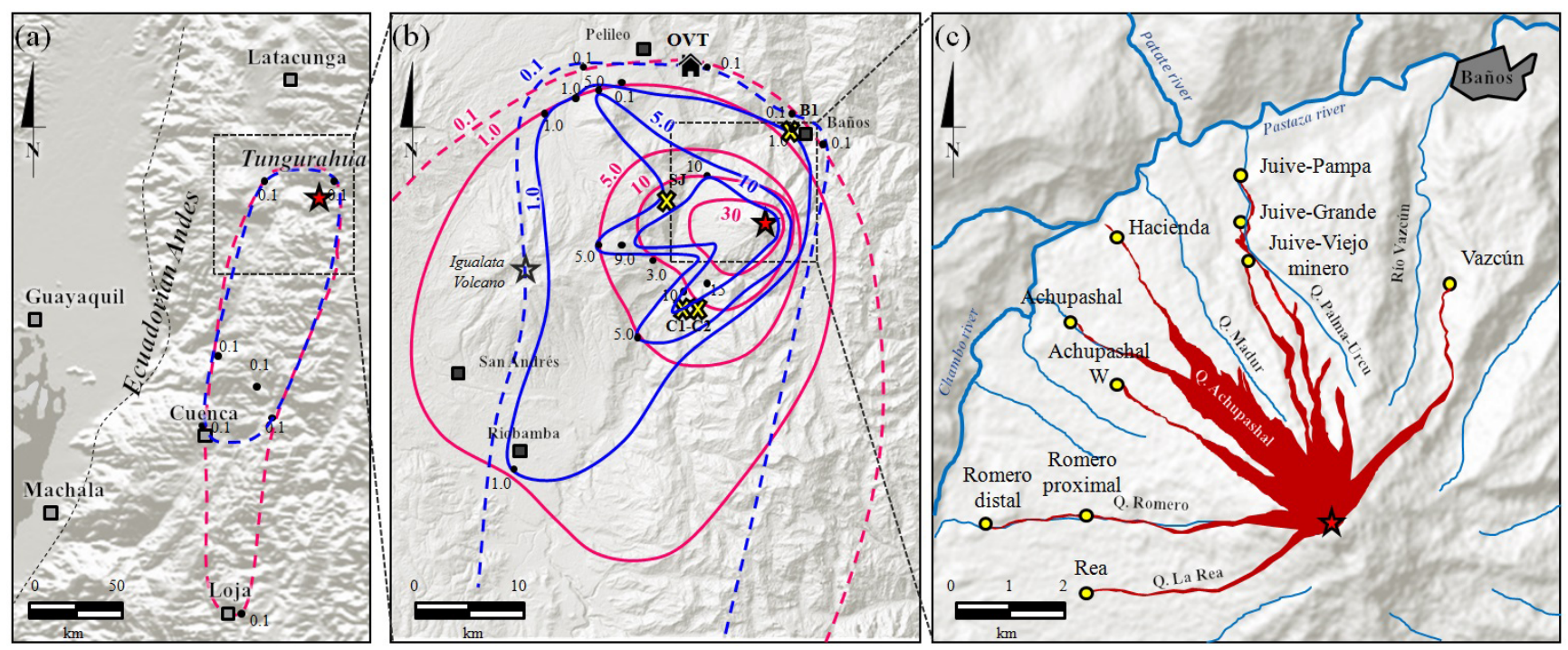

Figure 1. Pyroclastic deposits of the February 2014 eruption of Tungurahua volcano. (a, b) Isopach maps of tephra fall deposits associated with the 1-14 February 2014 eruptive period in millimetres (magenta: scenario A; blue: scenario B). Black circles: field measurements ; yellow crosses: samples for grain-size analysis. See Fig. 5 for details on the field observations. (a) Distal and (b) proximal distribution. (c) Distribution of PDCs from the 1 February eruption (red area), modified after Hall et al. (2015). Yellow circles represent the position for the field observation of PDC fronts (Table A1).

sentially in proximal areas, where only 17 data points cover a $20 \mathrm{~km}$ diameter around the vent (Fig. 1a-b). The elliptical scenario (A) is thought as a maximum volume endmember, yet some data points fall in a thicker isopach as they display. The second case (minimal volume) accounts for all data points and assumes that PDCs' elutriation had a major influence on the proximal thickness of the fallout deposits, as already documented for other eruptions of Tungurahua (e.g. Bernard et al., 2013, 2016; Eychenne et al., 2012). The calculated volume of tephra fall deposit ranges from 4.55 to $27.0 \times 10^{6} \mathrm{~m}^{3}$, depending on the model and scenario (Table 1; see Appendix for the method). Estimated volumes are smaller for the second case (dominated by PDCelutriation) and vary between the different estimation methods only between 4.55 and $6.40 \times 10^{6} \mathrm{~m}^{3}$. The elliptical scenario (A) gives larger volumes, especially using the Weibull method. A bulk deposit density of $760 \mathrm{~kg} \mathrm{~m}^{-3}$ was measured in the lab by weighing a known volume of sediment. However, Eychenne et al. (2013) showed that bulk density of tephra fall deposits vary spatially at Tungurahua and recommend assuming 980 to $1000 \mathrm{~kg} \mathrm{~m}^{-3}$. Using a density of $980 \mathrm{~kg} \mathrm{~m}^{-3}$, the total erupted mass would vary between 4.4 and $26.5 \times 10^{6} \mathrm{~kg}$ for a dense rock equivalent (DRE) volume between 1.8 and $10.7 \times 10^{6} \mathrm{~m}^{3}$.

The SSW tephra dispersion is not frequent at Tungurahua but has been reported before (e.g. February 2008 in Steffke et al., 2010 and the 1916-1918 eruption in Le Pennec et al., 2012). It seems to be the result of an infrequent S-oriented wind direction.

\subsubsection{Plume observations and wind analysis}

The Washington Volcanic Ash Advisory Center (VAAC) reported a column height of $13.72 \mathrm{~km}$ after 22:45 UTC on 1 February 2014 (http://www.ssd.noaa.gov/VAAC/ARCH14/ TUNG/2014B020235.html). The tephra cloud was mainly dispersed in a very uncommon pattern toward the SW and SSW, being divided into two fly levels $(<7.6$ and $>7.6 \mathrm{~km}$ a.s.1., Fig. 2a). The column source was associated with a hotspot on the Goes-13 McIDAS images, with the hottest pixel reaching $65^{\circ} \mathrm{C}$. As measured from the images of the GOES-8 satellite, the plume was dispersed to $185^{\circ}$ azimuth, with an average speed of $42.3 \mathrm{~km} \mathrm{~h}^{-1}$, and an expansion of ca. $0.16 \mathrm{~km}^{2} \mathrm{~s}^{-1}$ with a total area of over $12000 \mathrm{~km}^{2}$ during the first $3.5 \mathrm{~h}$ after the eruption onset. Over the area of Tungurahua, annual wind directions at an altitude of $15 \mathrm{~km}$ a.s.l. mostly blow toward the NW with speed magnitudes of 0 to $20 \mathrm{~m} \mathrm{~s}^{-1}$, whereas the January to March tendency is NW for speeds of 0 to $10 \mathrm{~m} \mathrm{~s}^{-1}$ but mostly $\mathrm{E}$ for speeds of 10 to $20 \mathrm{~m} \mathrm{~s}^{-1}$ (Fig. 2b, c). In all the time series, less than $1 \%$ correspond to SSW directions (180 to $210^{\circ}$ azimuth).

\subsubsection{Stratigraphy and lithologic components}

The composite stratigraphic column of tephra fall deposit consists of three recognisable layers (Fig. 3). The complete sequence is visible at Palictahua (sample P1) but remains incomplete in most outcrops. The basal layer (1) is a thin greyish to reddish, fine-grained ash strata, $<1 \mathrm{~mm}$ in thickness. It was only identified in a few locations $\mathrm{W}$ from the crater 
Table 1. Volume, mass and source parameters for the tephra fall deposit. See Appendix and Table A2 for details.

\begin{tabular}{|c|c|c|c|c|c|c|c|}
\hline Method & $\begin{array}{l}\text { Er. vol. }{ }^{\mathrm{a}} \\
\left(10^{6} \mathrm{~m}^{3}\right)\end{array}$ & $\begin{array}{l}\text { Er. mass }{ }^{\mathrm{b}} \\
\qquad\left(10^{9} \mathrm{~kg}\right)\end{array}$ & $\begin{array}{r}\mathrm{DRE}^{\mathrm{c}} \\
\left(10^{6} \mathrm{~m}^{3}\right)\end{array}$ & Mag. ${ }^{d}$ & $\begin{array}{l}\mathrm{Col}^{\mathrm{e}} \\
(\mathrm{km})\end{array}$ & $\begin{array}{r}\text { Mean/peak MDR } \\
\left(10^{6} \mathrm{~kg} \mathrm{~s}^{-1}\right)\end{array}$ & Mean/peak $I .{ }^{\mathrm{f}}$ \\
\hline \multicolumn{8}{|c|}{ Exponential thinning } \\
\hline Scenario A & 9.94 & 9.74 & 3.94 & 2.99 & 11.2 & $3.87 / 1.80$ & $9.59 / 10.3$ \\
\hline Scenario B & 4.55 & 4.46 & 1.80 & 2.65 & 9.13 & $1.77 / 8.26$ & $9.25 / 9.92$ \\
\hline \multicolumn{8}{|l|}{ Weibull } \\
\hline Scenario A & 27.0 & 26.5 & 10.7 & 3.42 & 14.5 & $10.5 / 49.0$ & $10.0 / 10.7$ \\
\hline Scenario B & 6.40 & 6.27 & 2.53 & 2.80 & 9.98 & $2.49 / 11.6$ & $9.40 / 10.1$ \\
\hline \multicolumn{8}{|l|}{ Power law } \\
\hline Scenario A & 10.8 & 10.6 & 4.27 & 3.02 & 11.4 & $4.20 / 29.6$ & $9.62 / 10.3$ \\
\hline Scenario B & 5.30 & 5.19 & 2.10 & 2.72 & 9.50 & $2.06 / 9.62$ & $9.31 / 9.98$ \\
\hline \multicolumn{8}{|c|}{$\begin{array}{l}\text { Er. vol.: erupted volume; Er. mass: erupted mass; DRE: dense rock equivalent volume; Mag.: magnitude; Col.: column heigh } \\
\text { discharge rate; Mean/peak } I .: \text { intensity. } \\
\text { a See Appendix for erupted volume parameters and method. } \\
\text { b } \\
\text { ceposit mass }=\text { volume } \times \text { density taking a density equal to } 760 \mathrm{~kg} \mathrm{~m}^{-3} \text { (deposit density). } \\
\text { c DRE volume }=\text { (deposit mass) } / \text { (magma density) taking a magma density equal to } 2450-2500 \mathrm{~kg} \mathrm{~m}^{-1} \text { (andesite magma). } \\
\text { d Magnitude }=\log _{10} \text { (deposit mass) }-7 \text { (Pyle, 2000). } \\
\text { e } \text { Using the Sparks et al. (1997) model for a sustained plume, } H_{T} \text { is related to the MDR (in this case, the mean MDR): } H_{T}= \\
\text { f }=\end{array}$} \\
\hline
\end{tabular}
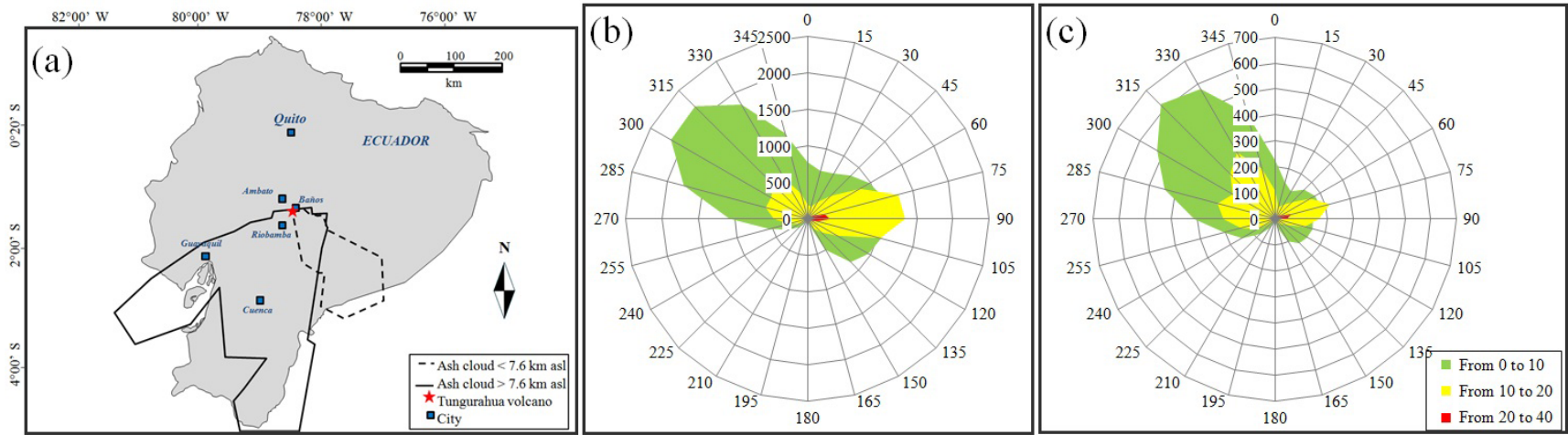

Figure 2. Plume dispersion and wind patterns. (a) Ash cloud dispersion during the 1 February 2015 eruption at different fly levels $(<7.6$ and $>7.6 \mathrm{~km}$ a.s.1.), as obtained from VAAC. (b, c) Rose diagrams showing the frequency of the wind direction at an altitude of $15 \mathrm{~km}$ a.s.1. during the whole year and from January to March (data acquired from 1999 to 2011). The colour of the series represents the wind speed measured in metres per second.

(Fig. 3). Above, layer 2 is thicker (1-8 mm) and formed of a dominant fraction of dense, black and angular fragments with maximum size varying from 6 to $9 \mathrm{~mm}$ in diameter (38\% averaged amount from different locations, Table 2). They have sharp edges and contain crystals of plagioclase $(\mathrm{Pl})$ and pyroxene $(\mathrm{Px})$. Light-grey to grey pumices reaching up to $10 \mathrm{~mm}$ diameter are also abundant $(26 \%)$ and are subangular in shape, with moderately micro-vesicular texture made of elongated to sub-spherical vesicles $(<1 \mathrm{~mm}$, Fig. 3$)$. Its matrix includes nailed $\mathrm{Pl}$ phenocrysts reaching $1 \mathrm{~mm}$ and minor presence of Px. Dark-grey to reddish scoria fragments (5 to $8 \mathrm{~mm}$ diameter) represent about $17.1 \%$. They are blocky, sub-rounded to sub-angular, with a vitreous ground- mass and high presence of non-elongated irregular-shaped vesicles, reaching 6 to $9 \mathrm{~mm}$ diameter. This layer also contains a subordinate altered lithics fraction $(11 \%)$ and scarce glassy particles ( $8 \%$, Table 2). Ultimately, the top layer (3) is very thin $(<1 \mathrm{~mm})$ and consists of Px and Pl crystals and abundant juvenile volcanic glass (Fig. 3). It also comprises reddish, non-vesicular, dense altered fragments and white particle aggregates. At greater distances from the vent (e.g. Penipe, $14.3 \mathrm{~km}$ southwest), volcanic glass is a major component $(>50 \%)$. It has a curviplanar surface and sharp morphology, in some cases of "shard" type, transparent to semi-transparent and black to clear brown in colour. It is accompanied by Pl-free euhedral crystals (15\%), in most cases 


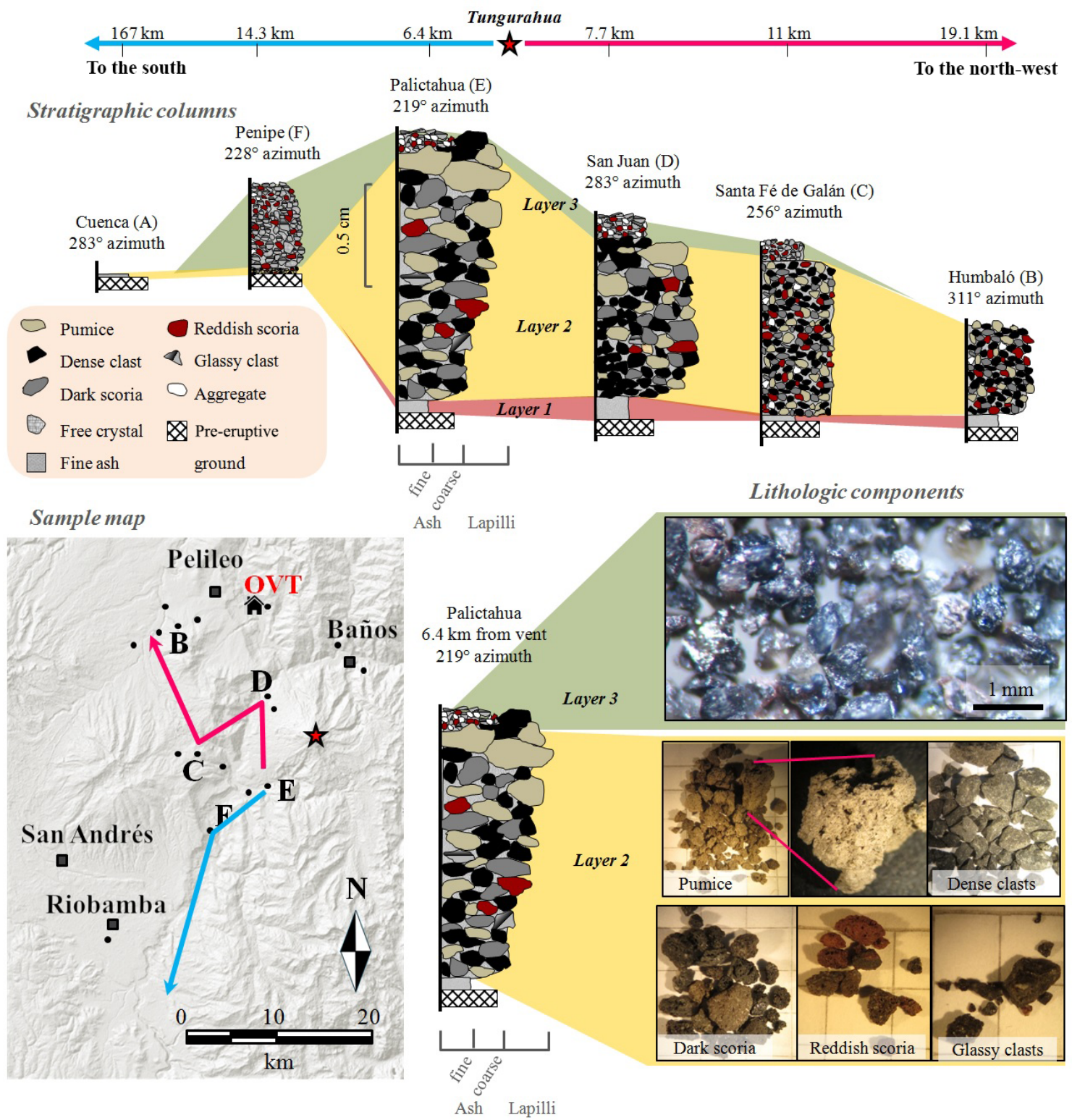

Figure 3. Field observations, stratigraphy and lithologic components of tephra fall deposits of the February 2014 eruption.

Table 2. Componentry results of tephra samples.

\begin{tabular}{|c|c|c|c|c|c|c|c|c|c|c|}
\hline Sample & Lat $(\mathrm{S}) / \operatorname{long}(\mathrm{W})$ & Unit & Fraction $(\mu \mathrm{m})$ & $\mathrm{L}$ & $\mathrm{S}$ & $\mathrm{P}$ & G & $\mathrm{AL}$ & $\mathrm{FC}$ & AG \\
\hline SJ & $1^{\circ} 27^{\prime} 13^{\prime \prime} / 78^{\circ} 30^{\prime} 38^{\prime \prime}$ & Layer 2 & $250-500$ & 62 & 17.1 & 16.2 & 0 & 5.2 & 0 & 0 \\
\hline $\mathrm{C} 1$ & $1^{\circ} 32^{\prime} 53^{\prime \prime} / 78^{\circ} 29^{\prime} 44^{\prime \prime}$ & Layer 2 & $315-350$ & 35.4 & 15.1 & 37.6 & 6.8 & 5.2 & 0 & 0 \\
\hline $\mathrm{C} 2$ & $1^{\circ} 32^{\prime} 47^{\prime \prime} / 78^{\circ} 29^{\prime} 49^{\prime \prime}$ & Layer 2 & $250-500$ & 23.8 & 19.6 & 37.8 & 8.4 & 10.5 & 0 & 0 \\
\hline Humbalo & $1^{\circ} 22^{\prime} 59^{\prime \prime} / 78^{\circ} 31^{\prime} 48^{\prime \prime}$ & Layer 2 & $315-500$ & 33 & 15.9 & 17.8 & 12.1 & 21 & 0 & 0 \\
\hline Palictahua & $1^{\circ} 31^{\prime} 27^{\prime \prime} / 78^{\circ} 29^{\prime} 52^{\prime \prime}$ & Layer 2 & $315-500$ & 37 & 16.3 & 28.4 & 4.26 & 14 & 0 & 0 \\
\hline Penipe & $1^{\circ} 34^{\prime} 10^{\prime \prime} / 78^{\circ} 31^{\prime} 43^{\prime \prime}$ & Layer 3 & $315-500$ & 0 & 0 & 0 & 60 & 25 & 15 & 0 \\
\hline Pillate & $1^{\circ} 27^{\prime} 32^{\prime \prime} / 78^{\circ} 31^{\prime} 09^{\prime \prime}$ & Layer 3 & $315-500$ & 0 & 0 & 0 & 74.3 & 7.8 & 15 & 2.5 \\
\hline
\end{tabular}

Fraction: grain-size range in which the analysis was made; L: lithics (including non-altered dense material); S: scoria (vesiculated, dark coloured); P: pumice (light coloured, highly vesiculated, often glassy); G: volcanic glass; AL: altered fragments; FC: free crystals; AG: aggregates. 
Table 3. Grain-size parameters for the tephra samples.

\begin{tabular}{|c|c|c|c|c|c|c|c|c|c|c|c|c|c|}
\hline Samp. & Lat (S)/long (W)/Alt (m) & $D(\mathrm{~km})$ & Dir. $\left({ }^{\circ}\right)$ & Md & $\mathrm{Mz}$ & $\sigma_{1}$ & Sk & KG & M1 & M2 & M3 & Type & Sort. \\
\hline P1 & $1^{\circ} 30^{\prime} 56^{\prime \prime} / 78^{\circ} 28^{\prime} 49^{\prime \prime} / 2434$ & 6.36 & 219.1 & & & & & & & & & & \\
\hline $\mathrm{B} 1$ & $1^{\circ} 24^{\prime} 0.4^{\prime \prime} / 78^{\circ} 25^{\prime} 7.5^{\prime \prime} / 1830$ & 8.4 & 19.3 & 2.41 & 2.32 & 0.94 & -0.2 & 1.12 & 2.66 & & & $\mathrm{U}$ & MS \\
\hline $\mathrm{C} 1$ & $1^{\circ} 32^{\prime} 53^{\prime \prime} / 78^{\circ} 29^{\prime} 44^{\prime \prime} / 2962$ & 10.3 & 212.5 & 0.64 & 0.78 & 0.57 & 2.18 & 7.92 & 0.5 & & & $\mathrm{U}$ & MWS \\
\hline $\mathrm{C} 2$ & $1^{\circ} 32^{\prime} 47^{\prime \prime} / 78^{\circ} 29^{\prime} 49^{\prime \prime} / 2984$ & 10.4 & 213 & 1.36 & 1.04 & 1.36 & -0.4 & 2.46 & 1.5 & -1 & & $\mathrm{~B}$ & PS \\
\hline SJ1 & $1^{\circ} 27^{\prime} 13^{\prime \prime} / 78^{\circ} 30^{\prime} 38^{\prime \prime} / 2447$ & 7.4 & 283 & 1.36 & 1.04 & 1.36 & -0.4 & 2.45 & 3.73 & 2.5 & -2.16 & $\mathrm{~T}$ & PS \\
\hline
\end{tabular}

$D$ : direct distance from the crater; Dir: orientation of crater-sample vector to the north; Md: median particle diameter; Mz: mean particle diameter; $\sigma_{1}$ : deposit sorting;

Sk: deposit skewness; KG: kurtosis; modes (1,2 and 3) are represented by M1, M2 and M3.

All grain-size distribution values expressed in $\phi$. Sample P1 was only analysed for lithology.

U: unimodal; B: bimodal; T: trimodal; MS: moderately sorted; MWS: moderately well sorted; PS: poorly sorted.

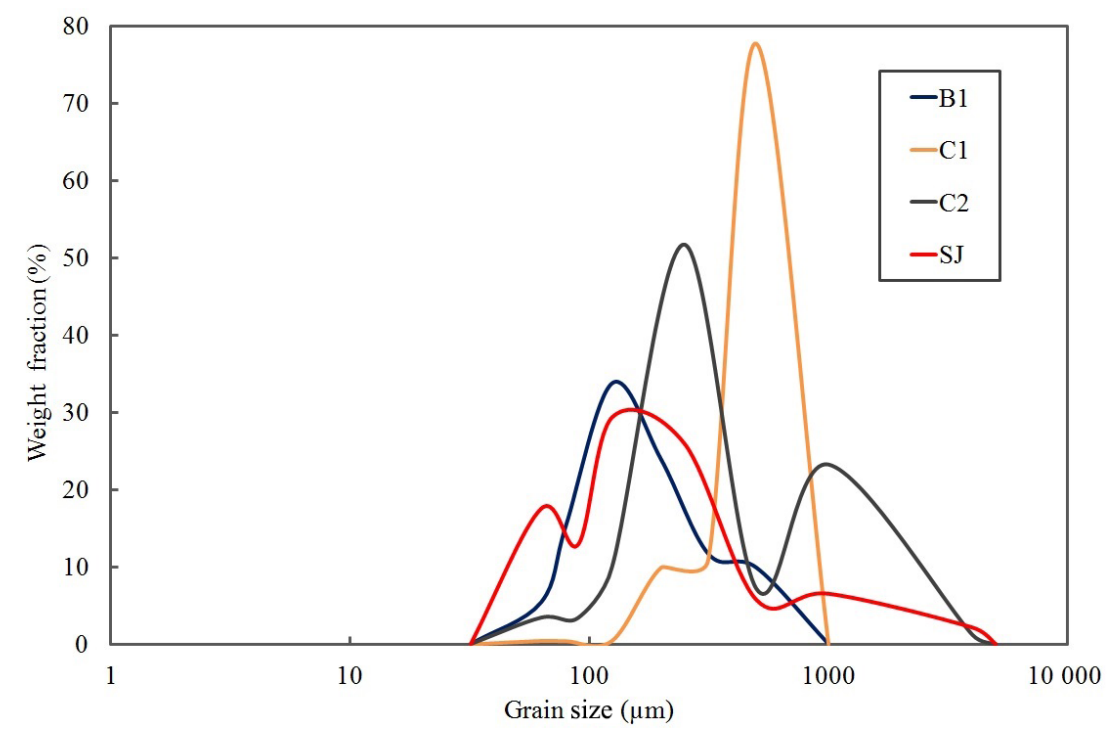

Figure 4. Grain-size analysis for samples from tephra fall collected around Tungurahua two weeks after eruption.

fractured, and rounded to polygonal-shaped reddish altered fragments $(25 \%)$. Samples further collected in situ (during the ash sedimentation over plane surfaces) at Pillate after discrete explosions in mid-February 2014 are mostly compound by black to brown curviplanar volcanic glass $(74.3 \%)$, free crystals $(15.4 \%)$, altered lithics $(7.8 \%)$ and few aggregates $(2.5 \%)$.

\subsubsection{Grain size of tephra fallout}

Four samples collected from tephra fall deposits were sieved for grain-size analysis (Table ). Samples B1 and C1 show unimodal distribution, whereas $\mathrm{C} 2$ and $\mathrm{SJ}$ are bimodal and trimodal, respectively (Fig. 4).

Sample B1 is composed of coarse to very fine ash (mode at $2.66 \phi$ ), with sorting being moderate (according to the classification of Folk and Ward, 1957) or very well sorted (according to Cas and Wright, 1987) and with a coarse-skewed distribution.

Sample C1 is mostly made up of coarse ash (mode at $1 \phi$ ), showing the same sorting as B1 and a very fine skewed distribution.
Sample C2 is bimodal (1.5 and $-1.0 \phi)$ and it is mostly composed of fine lapilli and coarse to medium-sized ash, poorly to well sorted (depending on the classification applied: Folk and Ward, 1957; Cas and Wright, 1987, respectively) and very coarsely skewed.

Sample SJ has a singular trimodality $(3.73,2.5$ and $-2.16 \phi)$. It contains a low amount $(<15$ wt. \%) of coarse material (medium lapilli to coarse ash), a notable proportion (ca. $60 \mathrm{wt} . \%$ ) of medium to fine ash, and less very fine ash (ca. $25 \mathrm{wt} . \%$ ), being poorly sorted and coarsely skewed. All the samples are leptokurtic (i.e. better sorted than a standard deviation).

\subsection{Pyroclastic density currents}

PDCs branched into at least nine valleys from the N, W and SW flanks of the volcano and reached the base of the edifice in several locations, endangering the main road of the area (Fig. 1b). According to Hall et al. (2015) the deposit lengths and approximate values for channel widths and deposit thickness return bulk volume estimates of $\sim 1.2 \times 10^{6} \mathrm{~m}^{3}$, yet this 
is based on constant thicknesses extrapolated from final lobes and may be exaggerated.

\subsubsection{Dynamics of PDCs}

PDCs were mainly generated during the second (22:32) and third (main, 22:39) major explosions on 1 February. Direct and thermal footage (IG, http://www.igepn.edu.ec) reveals that the second explosion was accompanied by PDCs flowing only in the upper flanks (ca. $500 \mathrm{~m}$ below crater). The third explosion developed at least two PDC pulses that flowed down the nine ravines of the flanks (Table A1, Fig. 5). A first pulse in the upper Achupashal drainage surpassed the previous flows and flowed down to ca. $3500 \mathrm{~m}$ a.s.l. on the NW flank. The second pulse was greater, with PDCs flowing rapidly down the SW valleys (Rea and Romero) and apparently simultaneously filled the upper Achupashal and Juive drainages as well as the Vascún Valley. It seems that PDCs were much faster in the Vascún Valley than in the Achupashal drainage, and that the slowest descending flows were those from the Juive drainage.

\subsubsection{Morphology of PDCs}

Typically, sediment morphologies showed levees made of large clasts producing self-channelisation with depleted inner channels in running parts, whereas lobes with tongue shapes developed at final local runout distances (Fig. 5-7a). Interestingly, lobes could form even in very steep setting $\left(>25^{\circ}\right.$ slope, e.g. Juive-Viejo-Minero Fig. 5d), whereas they could overrun long flat distances in other places (e.g. Pondoa). Two final lobes are found $<1 \mathrm{~m}$ from a cliff and on a very inclined bed (Vascún and Juive-Viejo-Minero, Fig. 5a and d). The Juive-Grande final lobe is found at an almost right angle to the general slope and deviated in an artificial trench created to protect the main road from lahars, proving its efficiency for slow currents (Fig. 5c). PDCs travelling in the Hacienda Valley were confined in a very narrow ravine $(<10 \mathrm{~m})$ where they could reach very low parts of the cone (Fig. 5e). They crossed the main road below the bridge without any damages. There, a lobe shape is scarred by a re-incision, the surface of the scar having a distinct colour due to the absence of a final ash draping (Fig. 5e). At Achupashal the most distal deposits consist of two superposed PDC lobes of contrasting componentry and grain-size distribution (Fig. 5f).

\subsubsection{Temperature and vegetation damages from PDCs}

Relatively low temperatures $\left(40-170^{\circ} \mathrm{C}\right)$ were measured between 8 and 14 days after the eruption at depth down to $1 \mathrm{~m}$ in several valleys (Table 4). No pattern could be recognised in the temperatures regarding PDCs' observed chronology, componentry, or morphology. For all PDC deposits, even when no thermometer was available, a warm temperature was manually checked to ensure the primary and recent nature of the deposits.
In some areas close to the PDC pathways, vegetation was affected and found with dead leaves in the days to weeks following the eruption. This contrasted with early observations ( 1 day after eruption) documenting leaves covered by ash but not burnt (H. Yepes, personal communication, 2014). Zones on outer curves of PDC pathways were affected by dead leaves on a much wider zone than in inner curves (Fig. 6). In the steep-sided, narrow valley of Juive-Pampa, PDCs got highly constrained in an edgy curve downstream a cliff (Fig. 6a-b). There, the outer valley sides were ploughed and scratched up to $15 \mathrm{~m}$ above the deposit surface during the flows, and young trees were unrooted or broken (Fig. 6c-d). Above, vegetation had dead leaves up to $60 \mathrm{~m}$ above the deposit surface on a very narrow zone (Fig. 6b). This corroborates with a video recording the growth of a co-PDC cloud at this location when flow fronts reached the zone (Diego C. F., Fig. 6a, e). Further, vegetation was affected in front of PDC lobe deposits up to $38 \mathrm{~m}$ in zones of high slope (e.g. JuiveGrande, Fig. 5c), but less than $1 \mathrm{~m}$ in flat terminal areas (e.g. Rea, Fig. 6f).

\subsubsection{Components of the PDC deposits}

The PDC deposits include blocks and bombs grouped in four types (Fig. 7b): (1) dense, seemingly glassy but microcrystalline clasts with pervasive fracture pattern, (2) dark to greenish, porous, glassy, cauliflower-shaped scoria, (3) lightgrey, micro vesicular, bread-crusted clasts with dense, fractured margins up to $3 \mathrm{~cm}$ thick, and (4) accidental lithics. According to Hall et al. (2015) the February eruption PDC deposits stratigraphy is segregated into a poorly developed top layer compound by both sub-angular to sub-rounded clasts of black vesiculated andesite (juvenile andesite), as well as subordinate number of grey dense andesite clasts, and a fines-rich lower layer is dominated by dense andesite clasts whose angular clasts have micro-fractures and chilled margins. Whereas this sequence can occur in some areas, many flows can be superimposed in other zones (e.g. $>4$ successive units in Juive-Pondoa). Individual lobes show very variable aspect in terms of largest clast size, surficial fine content, and most frequent type of clast encountered (Fig. 7cd). No tendency could be encountered with runout distance or eruption chronology. The superficial differences in content of fines is, however, absent in subsurface, where it seems constant between lobes with varying surface signatures. This suggests that the superficial content is a simple effect of local winds during emplacement. The size of the largest block fraction can vary from ca. $5 \mathrm{~cm}$ in some lobes to $>40 \mathrm{~cm}$ in others (Fig. 7c-d).

\subsubsection{Grain size of PDC deposits}

Most samples from PDCs present a main mode at $90 \mu \mathrm{m}$ $(3.5 \phi)$, with lesser secondary peaks at $250(2 \phi)$ and $500 \mu \mathrm{m}$ $(1 \phi)$ and follow a very consistent trend (black samples, 

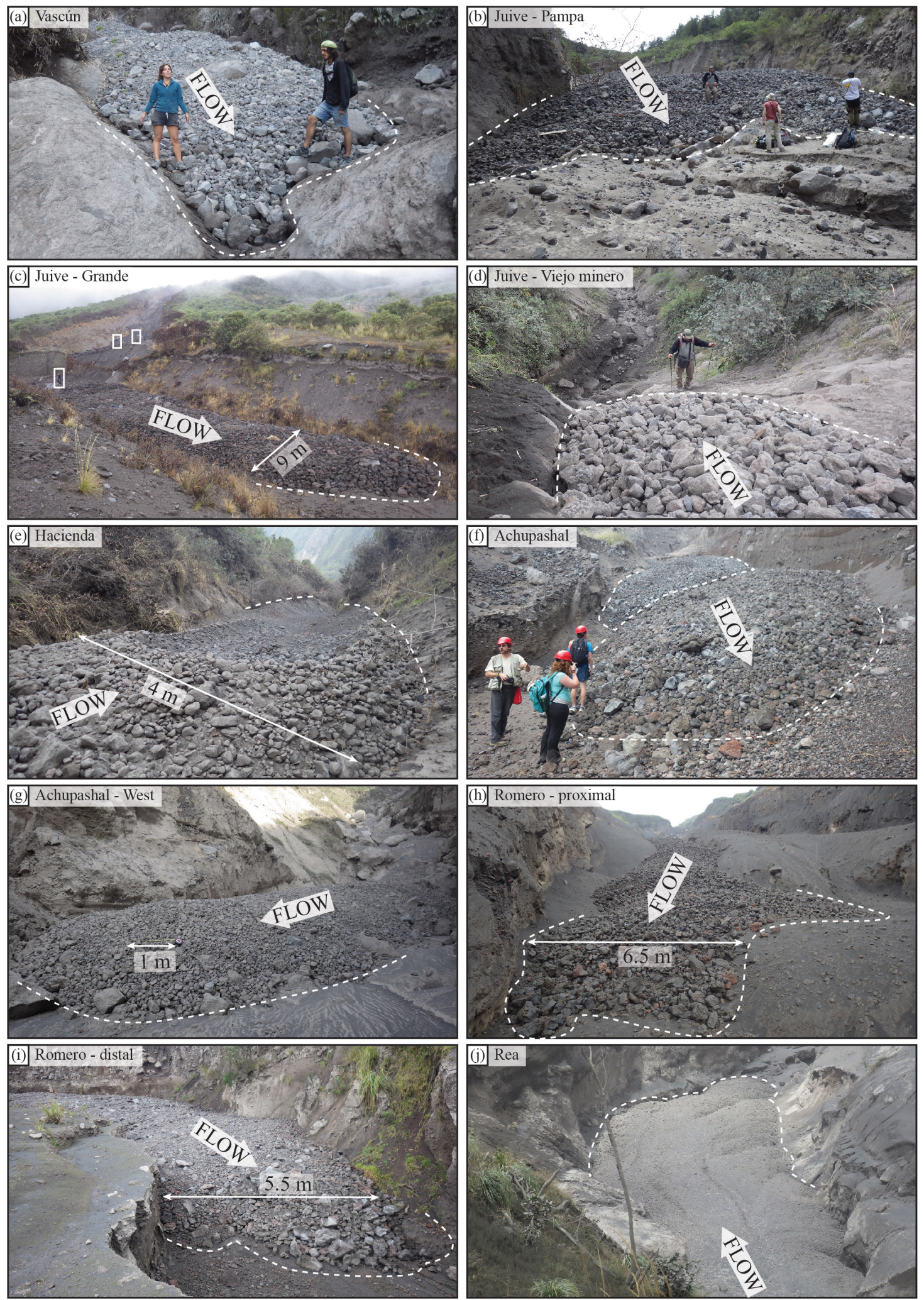

Figure 5. Picture of the final lobe in each valley: (a) Vascún, (b) Juive-Pampa, and (c) Juive-Grande; note deviation by an artificial trench. (d) Juive-Viejo-Minero; note cliff behind front. (e) Hacienda - the flow front continued through an inaccessible cliff; note the lobe scar (f) Achupashal; note two superposed lobes of contrasting content. (g) Achupashal-West. (h) Romero proximal - photographed after first rain.

(i) Romero distal lobe. (j) Rea (this lobe was not accessible, so the scale is not documented). 

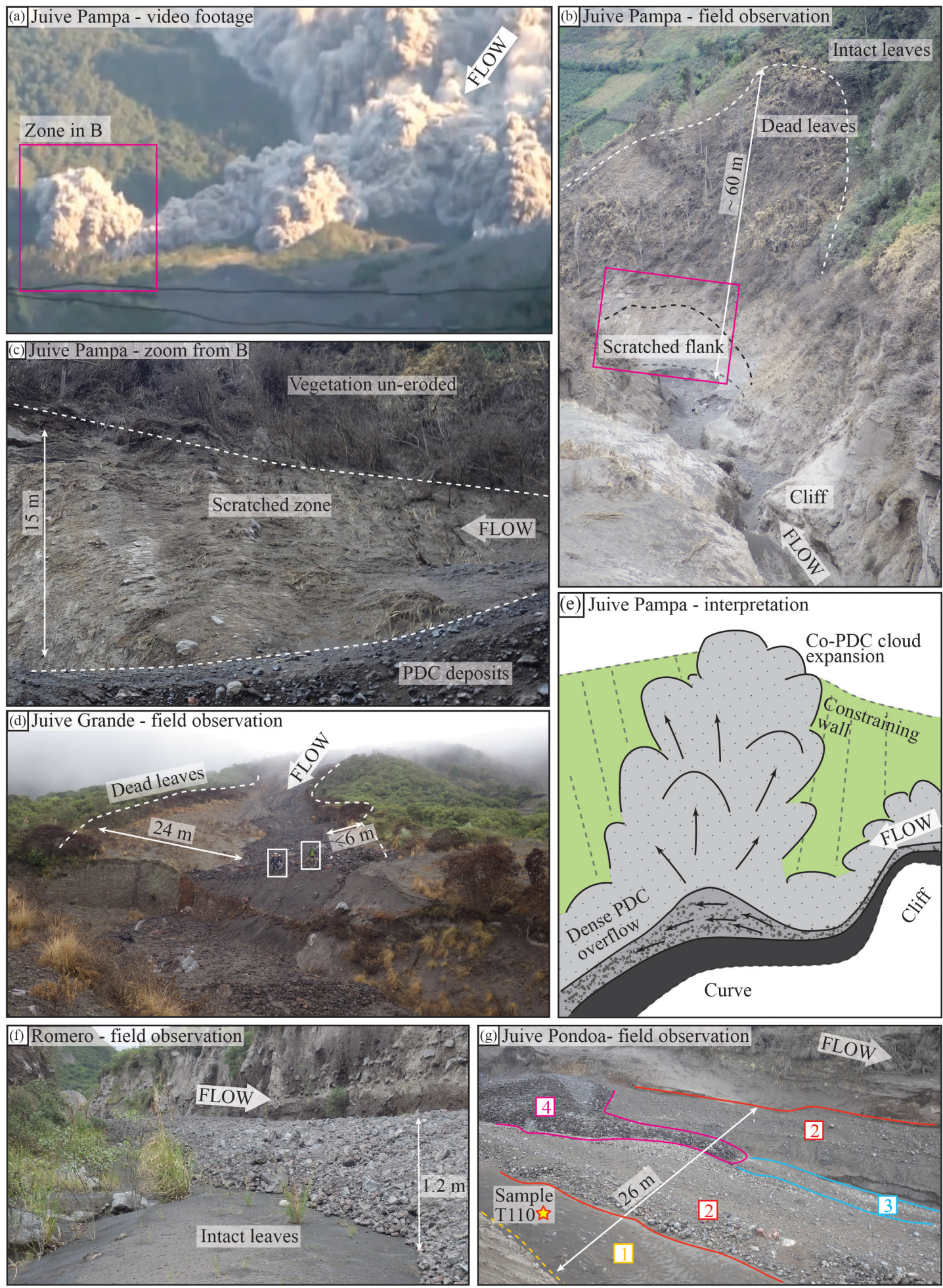

Figure 6. (a) Direct observation of PDCs during flow, YouTube video (C. F. Diego, https://www.youtube.com/watch?v=1pPr6wlFoDs). (b) Observation of PDCs' impacts in zone highlighted in panel (a), emphasising dead leaves due to co-PDC clouds in a topographically highly constrained valley, downstream of a cliff and on the outer overbank of a valley curve. (c) Zoom from B on the basal zone; note scratches. (d) The outer overbank of a valley curve shows no trees to the side of dense PDC deposits and damaged vegetation up to a distance of $24 \mathrm{~m}$, whereas damaged vegetation is visible only $6 \mathrm{~m}$ to the side of the inner curve. (e) Interpretative sketch for panels (a), (b), and (d). (f) In contrast, leaves are still standing less than $1 \mathrm{~m}$ from PDCs in the lower Romero Valley. (g) At least four successive units are recognised in the Juive drainage-Pondoa zone. 
Table 4. Temperature profiles within final PDC deposit lobes.

\begin{tabular}{|c|c|c|c|c|c|c|c|c|c|c|c|c|c|c|c|c|c|c|}
\hline Valley & \multicolumn{2}{|c|}{ J. Pampa-1 } & \multicolumn{2}{|c|}{ J. Grande } & \multicolumn{2}{|c|}{ J. Pampa-2 } & \multicolumn{2}{|c|}{ J. Chontal } & \multicolumn{2}{|c|}{ J. Pondoa-1 } & \multicolumn{2}{|c|}{ J. Pondoa-2 } & \multicolumn{2}{|c|}{ Achu. } & \multicolumn{2}{|c|}{ Achu-W } & \multicolumn{2}{|c|}{ Hacienda } \\
\hline Date & \multicolumn{2}{|c|}{$8 \mathrm{Feb}$} & \multicolumn{2}{|c|}{$8 \mathrm{Feb}$} & \multicolumn{2}{|c|}{$9 \mathrm{Feb}$} & \multicolumn{2}{|c|}{$9 \mathrm{Feb}$} & \multicolumn{2}{|c|}{$10 \mathrm{Feb}$} & \multicolumn{2}{|c|}{$10 \mathrm{Feb}$} & \multicolumn{2}{|c|}{14 Feb } & \multicolumn{2}{|c|}{14 Feb } & \multicolumn{2}{|c|}{14 Feb } \\
\hline Data & $D$ & $T^{\circ}$ & $D$ & $T^{\circ}$ & $D$ & $T^{\circ}$ & $D$ & $T^{\circ}$ & $D$ & $T^{\circ}$ & $D$ & $T^{\circ}$ & $D$ & $T^{\circ}$ & $D$ & $T^{\circ}$ & $D$ & $T^{\circ}$ \\
\hline & 50 & 128 & 45 & 84 & 5 & 43 & 50 & 52 & 55 & 65 & 5 & 35 & 45 & 43 & 40 & 62 & 30 & 39 \\
\hline & 55 & 153 & 60 & 92 & 30 & 53 & 65 & 58 & 75 & 83 & 45 & 80 & 55 & 84 & 45 & 63 & - & - \\
\hline & 65 & 158 & 95 & 99 & 50 & 86 & 90 & 58 & 100 & 102 & 90 & 107 & 60 & 70 & 60 & 81 & & \\
\hline & 70 & 171 & 100 & 97 & 70 & 105 & - & - & - & - & 105 & 95 & 65 & 76 & - & - & & \\
\hline & - & - & - & - & 80 & 120 & & & & & - & - & - & - & & & & \\
\hline
\end{tabular}

The date gives the measurement day; $D$ : depth in centimetres; $T^{\circ}:$ temperature in ${ }^{\circ} \mathrm{C}$.
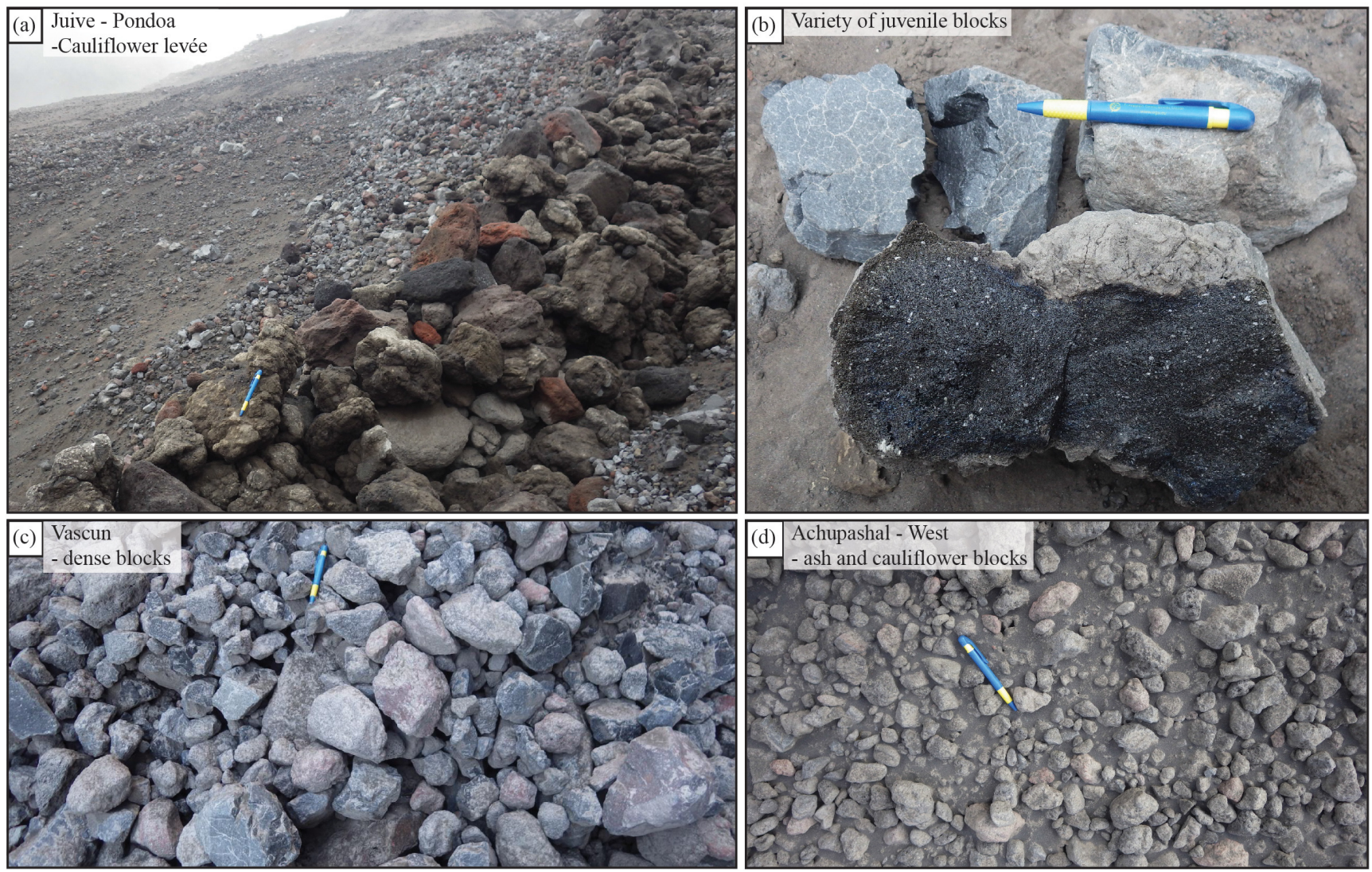

Figure 7. Surface observations of PDC deposits: (a) levee made of large cauliflower clasts. (b) Variability in juvenile blocks encountered, with dense (top left), cauliflower (lower part), and bread-crusted (top right) clasts. (c) A fines-depleted surface with large blocks vs. (d) a fines-rich surface with smaller blocks. Same pen for scale in each picture.

Fig. 8). Three samples slightly enriched in their fraction at $125 \mu \mathrm{m}$ ( $3 \phi$; cyan), yet this seems to only correspond to a minor measurement deviation and is not reflected in other fractions. Three samples have clearly distinct signatures switched towards the fines, both in the mechanical and laser analysis (red, blue, magenta). Two of these correspond to overflow sampling areas from co-PDC clouds rather than dense PDC deposits (Romero T104 and Pampa T10). The third fine-grained sample (blue, Pondoa T110; coordinates:
N0782730, E9842149) was collected on the lowermost deposit of a zone with at least four discrete PDC pulses at Juive Pondoa Valley (Fig. $6 \mathrm{~g}$ ). In terms of median diameter vs. sorting (Fig. 8c), the dense PDC samples plot in the field of "fallout" evidenced by Walker (1971), yet these measurements solely include the matrix fraction $(<2.8 \mathrm{~cm}$ diameter $)$. Interestingly, the samples from co-PDC clouds and Pondoa overlap the "surge" and the "flow" fields in Crowe and Fisher 

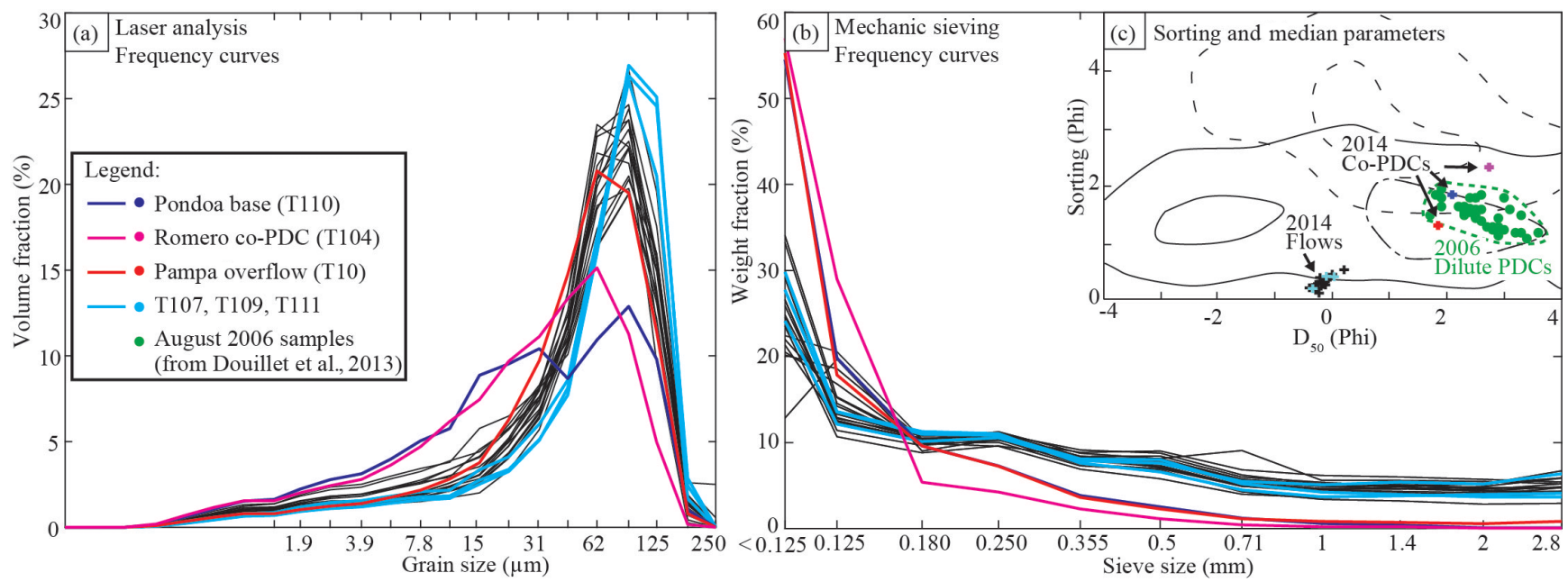

Figure 8. Grain-size analysis for samples from PDC deposits. Frequency curves for (a) laser and (b) mechanical sieving. (c) Sorting and median diameters calculated from the combined and interpolated curves for flows and co-PDC samples. Background: flow (dashed) vs. fall (plain) vs. surge (dotted) fields from Walker (1971) and dilute PDC samples from the August 2006 eruption in green.

(1973), and plot very close to the dilute PDCs from the 2006 eruption (Fig. 8c).

\subsubsection{Petrography and geochemistry from PDC blocks}

Thin sections were obtained from a juvenile cauliflower bomb. It is a dark porphyric (16\% phenocrysts) and faint trachytic andesites with profuse vesiculation (Fig. 9). The mineral assemblage is different to that observed in 2006 eruption products (Samaniego et al., 2011) and consists mostly of subhedral and prismatic Pl phenocrysts (17\%), Cpx (10\%) and Opx (2\%). Pl crystals show polysynthetic twins and clear zonation. Euhedral to subhedral Cpx show zoned rims and appear as single phenocrysts or as agglomerated rounded crystals. The Opx and Cpx glomeroporphyritic textures are occasionally present. The groundmass consists of magnetite and glass vesicles ( 25 and $31 \%$ respectively), plus Pl small acicular crystals $(17 \%)$ in a cryptocrystalline groundmass (Fig. 9c).

The major element bulk rock geochemical XRF analysis (Table 5) shows that the black vesicular juvenile scoria corresponds to a high-K (2.46 wt. \%) andesite $(59.41 \mathrm{wt}$. \% of $\mathrm{SiO}_{2}$ ) composition, while the two dense blocks analysed are medium-to-high K (1.87 to 2.01 wt. \%) andesites (58.33 to $59.80 \mathrm{wt} . \%$ of $\mathrm{SiO}_{2}$ ). Overall, these samples suggest a stable compositional trend in time, if compared to previous eruptive products of the 1999-2014 eruptive cycle (e.g. Samaniego et al., 2011; Myers et al., 2014). According to traditional classification schemes of igneous rocks from Le Maitre et al. (1989) and Shand (1948), this sample is included in the calcalkaline series and presents peraluminous composition, respectively.
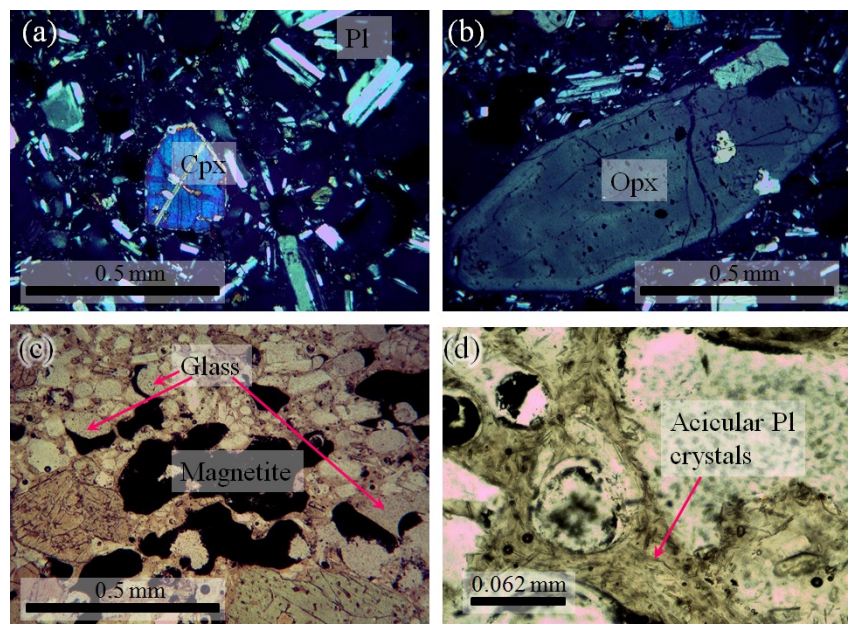

Figure 9. Texture and mineral assemblage of a juvenile, lowdensity scoria bomb revealed by optical microscope. The mineral assemblage consist of plagioclase (Pl), clinopyroxene (Cpx) and orthopyroxene (Opx) crystals, as seen in cross-polarised light $(\mathbf{a}, \mathbf{b})$. (c) Magnetite and volcanic glass vesicles observed in planepolarised light. (d) Cryptocrystalline groundmass with acicular Pl crystals observed in plane-polarised light.

\section{Discussion}

\subsection{Data reliability}

Biass et al. (2014) describe that the error in the quantitative interpretation of tephra fall deposits may originate from three different sources: (1) reworking processes before data acquisition, (2) the quality of the measurements in the field and (3) the interpretative choices made during contouring of both isopleth and isopach maps. Smaller datasets $(<20$ data 
Table 5. Major element bulk rock geochemical XRF analysis.

\begin{tabular}{|c|c|c|c|}
\hline Major element & Scoria-1 & Dense-1 & Dense-2 \\
\hline $\mathrm{SiO}_{2}$ & 59.61 & 59.80 & 58.33 \\
\hline $\mathrm{TiO}_{2}$ & 0.82 & 1.12 & 0.75 \\
\hline $\mathrm{Al}_{2} \mathrm{O}_{3}$ & 15.27 & 15.71 & 16.29 \\
\hline $\mathrm{FeO}$ & 7.40 & 7.57 & 8.14 \\
\hline $\mathrm{MgO}$ & 2.75 & 3.06 & 3.31 \\
\hline $\mathrm{CaO}$ & 7.25 & 7.08 & 8.01 \\
\hline $\mathrm{Na}_{2} \mathrm{O}$ & 3.91 & 3.89 & 3.92 \\
\hline $\mathrm{K}_{2} \mathrm{O}$ & 2.46 & 2.01 & 1.87 \\
\hline Total & 99.91 & 99.99 & 99.98 \\
\hline
\end{tabular}

points) are associated with the largest uncertainties, typically exceeding $10 \%$ in volume estimates (Engwell et al., 2013), and 7 to $30 \%$ in the isopach areas or even more in proximal zones (Klawonn et al., 2014). This is in particular increased by amorphous shapes of isopachs due to wind variability, such as documented at Tungurahua itself (e.g. during the 2012-2013 eruption: Bernard et al., 2013).

Here, the data were obtained exclusively from flat horizontal surfaces without signs of reworking. Precise direct thickness measurements delivered uncertainties of less than $0.5 \mathrm{~mm}$, although weighting the amount of tephra fallen on a known area reveals to be a more accurate technique. As a direct consequence of fast reworking of tephra, only 23 sites were measured, and this, mostly in proximal areas, where erosion did not affect the deposits. The uncertainties on volume estimates should thus be on the order of $10 \%$. An attempt to account for the subjectivity of isopachs drawing was made by presenting two end-member cases. Depending on the method, the volume estimates obtained with the isopachs of scenario B represent $23 \%$ (Weibull) to $49 \%$ (exponential and power law methods, respectively) of the values obtained with the isopachs of scenario A. The "PDC-influenced" scenario is supported by the variable occurrence of a fines' blanket at the surface of different PDC lobes, showing that wind did mobilise further at least the final settling ash accompanying PDCs.

Field work on the fallout deposits was carried out 23 weeks after the eruption's onset, and tephra samples thus contain the signature from the paroxysm event of 1 February, as well as from the 2 weeks of subsequent lower intensity Strombolian activity. However, the tephra cloud accompanying the paroxysm propagated in a very unusual SSW direction, whereas the tephra clouds from the post-paroxysm activity followed the usual cloud pathway aligned with the westward wind direction. The signal thus seems to be largely the one from the main eruption due to the SSW elongated shape of the isopachs. The amount of tephra identified as deposited by the subsequent activity (2-14 February) is of the order of $1 \mathrm{~mm}$ in proximal areas along the dispersal axis produced by discrete, sporadic low-intensity explosions. In fact, one point collected on a solar panel in the village of Bilbao was cleaned by the IGEPN staff on 6 February and showed that about 1-2 $\mathrm{mm}$ of ash fall was deposited there after this date (Fig. A1).

\subsection{Components and plug occurrence}

The dense microcrystalline blocks with pervasive fracture patterns were found very breakable in the PDC deposits and cannot have been transported with such pre-existing weaknesses. The pervasive fractures are thus interpreted as prismatic cooling cracks, and they must have, at least partially, grown after deposition. The dense clasts must thus have been emplaced at a warm enough temperature. However, the microcrystalline textures rule out the possibility that the dense clasts were hot enough to result from quenching magma during the explosion. These clasts must thus have been part of a mass passing a long enough time in the conduit at intermediate temperature - in other words, a recently crystallised magma, yet not the fresh magma of the 1 February 2014 eruption. Considering the sudden and violent onset of the eruption, this mass likely represents a plug in the conduit. Further, the dense microcrystalline blocks found in PDC deposit probably represent the blocky equivalent to the dense porphyric, microcrystalline fraction in the thickest fallout unit (layer 2).

The bread-crust and cauliflower bombs found in the PDC deposit are, when preserved as large blocks, very fragile, and thus must have been emplaced in a relatively malleable, hot state. The presence of glass, bubbles and microvesicles with different elongation patterns is typical of explosive and Vulcanian eruptions (e.g. Wright et al., 2007). Polacci (2005) interpreted that juvenile pumices with elongated/rounded morphologies and bubbly/glassy textures represent the central part of a magmatic column during Plinian eruptions, where vesicles are free to grow and only subjected to elongational stresses, an interpretation transferable here. For broken pieces of scoria clasts, however, it is in no way trivial to identify which ones belong to the 1 February 2014 juveniles or are deposits from earlier PDCs from 2013, 2012 or before incorporated during flow bulking.

Interestingly, the light-grey, pumiceous type of pyroclasts can often be found filling decimetric cracks of the dense microcrystalline blocks, as observed by Hall et al. (2015). This texture may thus correspond to the first ascending magma that triggered the break of a plug.

\subsection{Origin of fallout deposits}

The three tephra fall layers have distinct signatures that allow their correlation to different events (Fig. 3).

Layer 1, with a basal stratigraphic position, whitish/reddish fine-grained ash content and location near the vent toward the NW is atypical. Three interpretations are envisaged: (1) a pre-existing deposit from a recent eruption, (2) a fallout deposit from the 1 February 
eruption but from the pre-paroxysmal phase, and (3) the distal signature of PDCs. Hall et al. (2015) interpreted for an "inner older layer" with "slightly coarser particles" in the co-PDC material that "its reddish color suggested that its source was the 14 July [2013] eruption". However, Le Pennec (this review) argued against such an origin for the reddish basal layer 1, emphasising that the 2013 eruption left a thin dark-toned tephra layer that would likely be rapidly eroded. The main explosions of the 1 February had a dispersion toward the SW, so if related to the 1 February eruption cluster, layer 1 likely belongs to the pre-paroxysm, weak explosions on 30-31 January. Finally, it could be envisaged that layer 1 represents the distal signature of elutriated ash from the PDCs (as suggested by Eychenne et al., 2012, for the 2006 eruption). The dispersal would thus possibly be elongated in the NW orientation of the PDCs and even have a basal stratigraphic position since it would be deposited from much lower flows.

Layer 2 is the thickest layer, and contains the SSW elongated isopach signature. The abundant porphyric, dense and dark andesite lapilli are interpreted to belong to a recently crystallised magma, yet not directly the 1 February 2014 events. They would thus represent lithics (sensu stricto). The abundance of these clasts in comparison to other juvenile fractions (i.e. dark scoria, pumice, volcanic glass) in addition to the presence of altered lithics in layer 2 further supports interpretation of a sudden and violent eruptive mechanism triggered by gas accumulation and destruction of a plug/magma solidification front (e.g. Morrissey and Mastin, 2000). The altered lithics would represent the eroded parts of the conduit's walls.

Contrasting, layer 3 presents high amount of juvenile material (volcanic glass $>50 \mathrm{vol} . \%$ ) and free crystals (15 vol. \%) together with abundant altered lithics (25 vol. \%), indicating the transitional behaviour between Vulcanian and Strombolian styles. Altered lithics are here interpreted to be eroded from the conduit walls by the fragmented magma, as well as remnants from the plug.

\subsection{PDC material}

\subsubsection{Flow bulking}

The low temperatures measured at PDC lobe deposits are striking in comparison with the simultaneous occurrence of carbonised wood fragments. This can be explained by the fact that there was only a low amount of hot juveniles. Wood in contact with hot juveniles was carbonised, yet there were not enough of these clasts to make the whole deposit hot. The low temperatures thus demonstrate that a large fraction of the material was cold and likely eroded on the flanks during transport (i.e. flow bulking), as suggested for previous events by Bernard et al. (2014).
A componentry analysis on rock fragments would lead to extreme uncertainties since no criteria permits to distinguish between juvenile material (i.e. from 2014) and scoria that were juveniles of the PDCs from, for example, July or August 2006, 2012 or 2013. Thus, temperature measurements deliver the strongest reliable insight into flow bulking here. A large part of the scoria material that seems to be fresh juvenile probably corresponds to material ejected during preceding small events from the previous years. This material that accumulated in the upper flanks would have been destabilised during the 1 February explosions and help to trigger the formation of PDCs. Thus, even if a relatively small eruption occurs, it can lead to formation of PDCs if material has previously accumulated without stabilisation on the upper flanks during preceding events.

\subsubsection{Grain-size distribution and transport processes}

No correlation of the grain-size curves with runout distance, componentry and morphology was observed, nor to any pathdependent abrasion. Two patterns are found from the grainsize data. The "dense PDC" pattern is fairly homogeneous, and no trend was identified. It plots in the fallout field of Walker (1971), yet the results are biased toward better sorting by the fact that only the fraction $<2.8 \mathrm{~cm}$ was sampled, whereas a large fraction of the distribution of these samples were blocks and lapilli (Douillet et al., 2013b, Fig. 8e). The "co-PDC cloud" pattern includes three samples and overlap on the "flow" and the "surge" fields of Walker (1971) and Crowe and Fisher (1973), as well as very close to the dilute PDCs from the 2006 eruption (Douillet et al., 2013b). Thus, the grain-size signature of the fine fraction of both the dense PDCs and co-PDC clouds is mainly a result of the transport process, as a dense mixture for the dense flows and dominated by elutriation and subsequent suspended transport for co-PDC clouds. No information regarding eruption chronology, fragmentation mechanism, or in situ abrasion related to travel distance is visible, and there is great homogeneity.

\subsubsection{Wind reworking}

The variability in the amount of ash visible at the surface of the PDC deposits was previously interpreted as representing two stages of the eruption. Although there may be more fines in basal units compared to the top layer in some particular cases, this is not systematic at all and seems to be due to wind during emplacement rather than reflecting the eruptive dynamics. This is further supported by the video footage of the eruption showing that co-PDC clouds were rapidly drifted by the wind in some ravines (C. F. Diego, YouTube). Sample T110 from the basal layer of Pondoa zone illustrates this further, since this PDC deposit surface was covered by at least three further co-PDC clouds and thus has a co-PDC cloud signature in its superficial grain size. Following these observations, a distal PDC influence in tephra fallout deposits 
is to be expected and justifies the scenario B for tephra analysis.

\subsubsection{PDC dynamics}

It seems that the Vascún and Juive drainage flows have more dense fractured blocks, whereas the western deposits are richer in cauliflower and altered clasts. This would go against the eruption dynamics chronology with initial plug destruction, since the first PDCs were emitted in the proximal Achupashal and then the onset of the third explosion triggered PDCs in the SW ravines (Rea and Romero), and only after that in the Vascún, Juive, lower Achupashal and Hacienda almost simultaneously (Fig. 1). The variability in componentry and aspect of the final lobes and channels might have a signature from the eruption dynamics, yet the first emitted flows were likely re-entrained during the main-PDC flows.

It is noteworthy that neither the characteristics of the PDC deposits nor the thermal and colour videos from the monitoring network (http://www.igepn.edu.ec) show any presence of lateral blast. In contrast to Hall et al. (2015), we instead interpret the origin of the PDCs as a result of flank loading from a vertically erupting column, and subsequent destabilisation of the material accumulated on the steep upper flanks, a mechanism quite similar to the 2006 PDCs (e.g. Kelfoun et al., 2009).

\subsubsection{Smooth valleys: increased mobility of small-volume flows}

Volume calculations of PDCs and incandescent bombs over the flanks of the volcano estimated by Hall et al. (2015) are about $5.7 \times 10^{6} \mathrm{~m}^{3}$. These measurements seem to be overestimated since they consider thicknesses at lower (thicker) emplacement areas and systematic value assignment. In fact, the thickness of the PDC deposits for the 2014 eruption is fairly unequal. Most of the material seems to be accumulated in discrete places and terminal lobes, but the majority of the pathway ravines were almost empty of PDC deposits and only had levees; some even showed signs of erosion (and thus flow bulking). Field work was carried out before any rain occurred, and thus there was no secondary transport by lahars. The first implication is that previously extrapolated PDC volume based on the thickness of terminal lobes may be fairly exaggerated. Without high-resolution topography data, we refrain from making any volume estimate for the PDCs.

Most importantly, the February 2014 PDCs illustrate a new danger of the ongoing eruption: even with a small volume, PDCs are able to travel further and further. This character is likely due to the fact that ravines have been stripped and eroded by 15 years of lahars and PDCs. There are no more obstacles to PDCs' flow, no trees or natural dams. Thus, even of small volumes, future PDCs at Tungurahua are likely to reach the lower inhabited areas both more easily (more frequently) and faster.

\subsection{A plug-driven onset evolving into an open conduit eruption}

No disequilibrium textures in $\mathrm{Pl}$ or Px were observed in thin sections (although deep petrological studies are necessary, as for the 2006 eruption, for example, Samaniego et al., 2011). This suggest that the February magma was not re-heated or mixed and that a quick quenching process, rock fracturing and eruption at the ejection level occurred without any evidence of interaction between two melts inside the magmatic reservoir. The geophysical background of inflation (Vallejo et al., 2014) and striking seismicity $48 \mathrm{~h}$ before the eruption onset are probably triggered by the pressurisation of the upper chamber due to the presence of a plug in the conduit (Fig. 10a). This rapidly evolved into a volcanic unrest and eruption.

According to the direct observations and timing of the eruption, a progressive plug failure is inferred, starting on 30 January and then evolving into a total plug destruction at 22:39 UTC (Fig. 10c) during the paroxysmal phase of explosive activity. This Vulcanian mechanism is also supported by the componentry of tephra fallout, and has already been described for previous eruptions at Tungurahua (e.g. Bustillos et al., 2016; Parra et al., 2016).

After this phase, the componentry of layer 3 may be interpreted as the result of an eruptive-style transition into an open-vent mechanism of Strombolian style, which is fully supported by the direct observations (Fig. 10d). The geochemistry of the sample analysed is in agreement with the composition of the products during the ongoing phase of Tungurahua (1999-2010), which mostly consist of andesites (58-59 wt. \% of $\mathrm{SiO}_{2}$; Samaniego et al., 2011; Myers et al., 2014). Even if there is general consensus in the mixing of a volatile-rich basaltic andesite with a degassed andesite magma during the eruption of 2006 (Samaniego et al., 2011; Myers et al. 2014), the composition remains strikingly stable in the last 15 years (1999-2014) of eruptions without notable changes in the feeding magma.

\subsection{Volume and style}

We suggest that scenario $\mathrm{B}$ is more realistic, due to a smaller mean relative squared error $(\sim 0.0050$ to 0.032 depending on model, Table 1). This scenario gives a volume estimate of $5.42 \pm 0.925 \times 10^{6} \mathrm{~m}^{3}$ (average between the three extrapolation methods).

Direct observations of the eruption columns together with volume extrapolation from the fallout deposit isopachs allow an estimation of the mass discharge rate (MDR) associated with the paroxysmal event mean $(42 \mathrm{~min})$ and peak $(9 \mathrm{~min})$ eruption duration. Following the physical model of eruptive column in Sparks et al. (1997) to scenario B, the maximum column height (HT) would range from 9.13 to $9.98 \mathrm{~km}$ in height above the crater (Table A2), in agreement with the height reported by the VAAC (14 km a.s.l.). 
(a) Prior February 2014 eruption

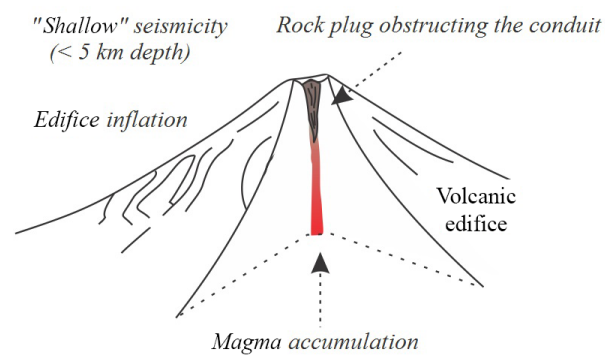

(C) February 1st eruption at 22:39 UTC Ash plume dispersed to the S-SW

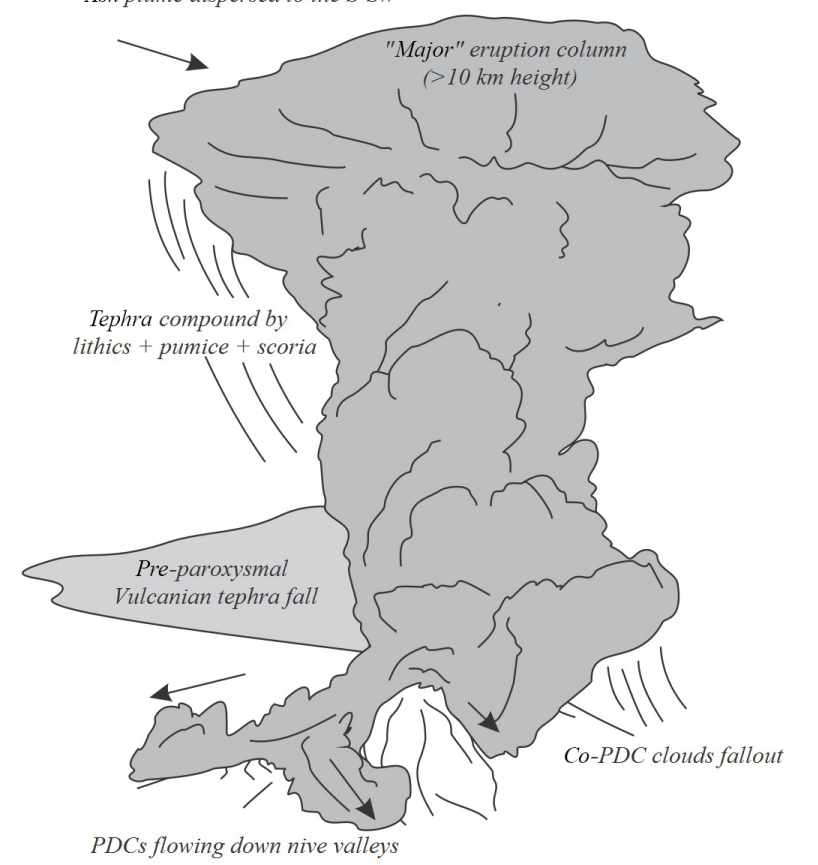

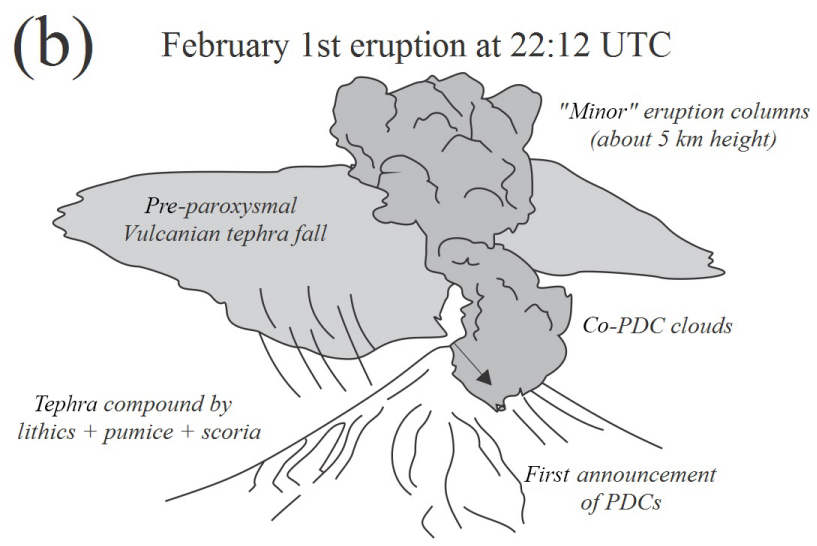

(d) Post-February 1st eruption at 23:36 UTC

Plume dispersion continues towards the south-southeast

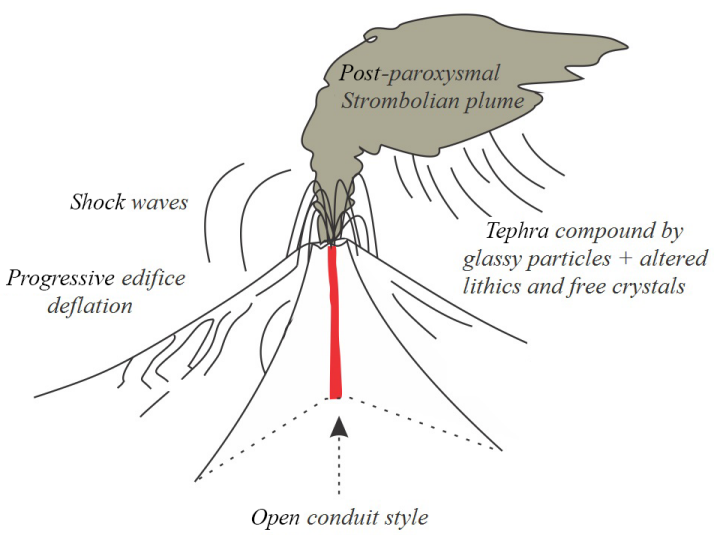

Figure 10. Dynamics of the February 2014 eruption at Tungurahua. (a) Pre-eruptive condition interpreted as plugging of the upper conduit. Fluid circulation cause alteration in the wall rock. The ascent of magma generates edifice inflation, and seismicity occurs only briefly before plug destruction due to faulting by overpressure. (b) The partial opening of the system generates small Vulcanian explosions and PDCs. (c) A major Vulcanian eruption with formation of a stratospheric column results from the total failure of the plug. PDCs descend the valleys on the flanks, transporting plug blocks, juvenile bombs and previously erupted material. (d) After the explosive paroxysm ends, the depressurisation of the volcano causes deflation and activity continues with an open-vent system with Strombolian activity. The juvenile magma is released with scarce content of lithics.

The method of Pyle (2000) was used to calculate the magnitude ( $M: 2.65$ to 3.42 ), intensity ( $I: 9.25$ to 10.02$)$ and peak intensity (PI: 9.92 to 10.69) for each isopach scenario (Table 1). The released tephra volume and maximum eruptive column height are consistent with a VEI of 2 for scenario B to 3 for scenario A (Newhall and Self, 1982). The column height and intensity suggest that the peak activity was similar to that of a small Subplinian eruption (in the Cioni et al.,
2015 , classification) yet the components of the tephra deposits and the development of the eruption are close to a Vulcanian style. In terms of fallout deposits, the February 2014 eruption seems to be similar in size to the ones from late 1999 and August 2001 ( $M$ from 2.7 to 3.2, $I$ from 6.5 to 7.0 and VEI 3: Le Pennec et al., 2012). The PDCs were of much smaller volume than the ones in August 2006, and roughly 


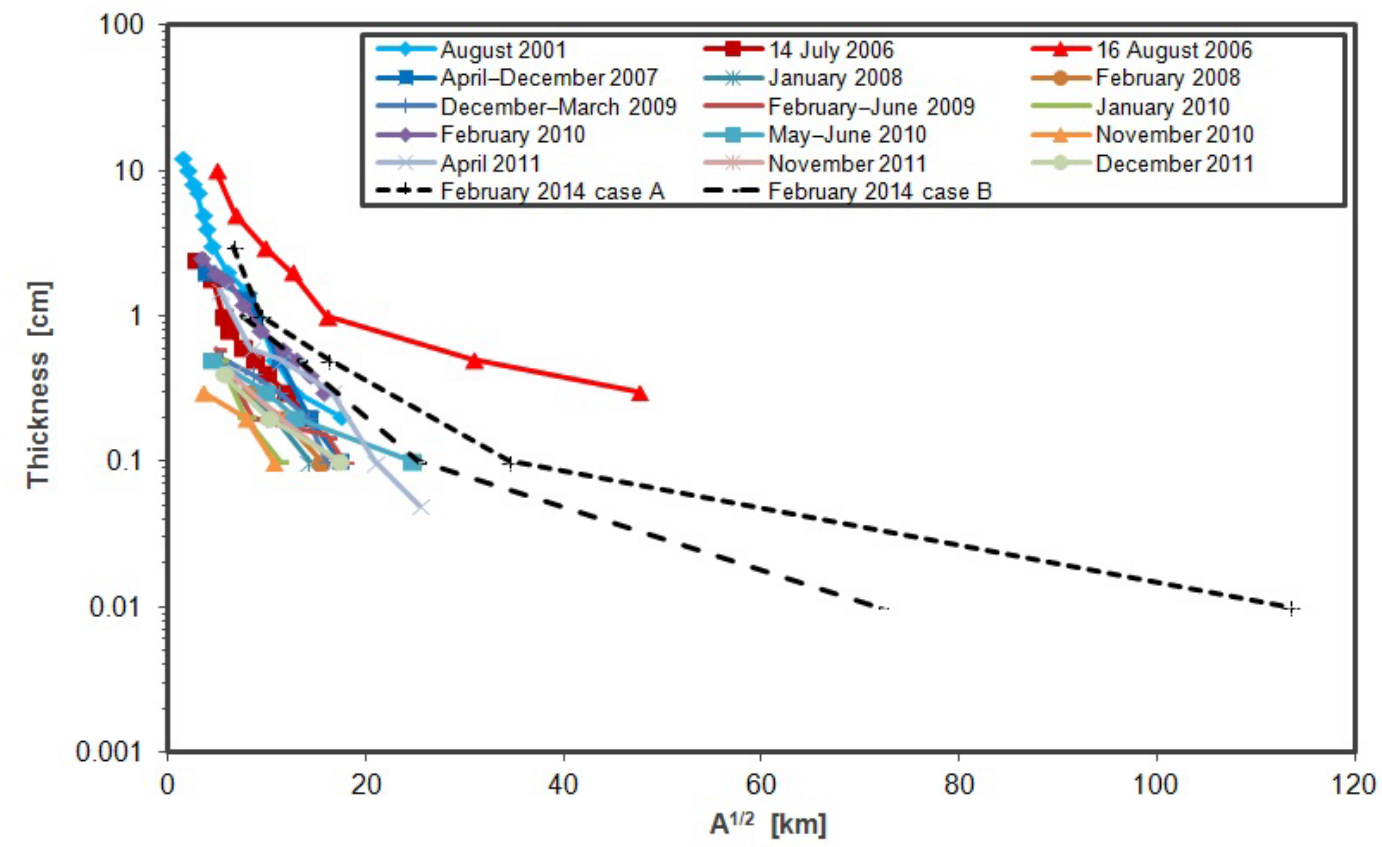

Figure 11. Plot of thickness $(\mathrm{cm})$ vs. square root area $(\mathrm{km})$ for tephra fall deposits from eruptions during the period 1999-2014 at Tungurahua volcano. Modified from Bustillos et al. (2016) and based on data from Jaya (2004), Troncoso et al. (2006), Bustillos (2010), Le Pennec et al. (2012), Bernard et al. (2013), and Bustillos et al. (2014).

comparable in size to the ones from July 2006 and July 2013 (Fig. 11).

\section{Conclusions}

The 1 February 2014 eruption of Tungurahua volcano was constrained through field studies, laboratory analysis and eruption chronology. Tephra fallout of volumes similar to those from the 1999 and 2001 eruptions were produced, together with the trigger of PDCs that flowed down to the base of the edifice through nine ravines. It corresponded to a moderate (VEI 2-3) Vulcanian-style eruption, one of the largest since the awakening in 1999.

The eruption can be summarised in three stages: (1) the onset of a striking seismic swarm of VT and LP events with few ash emissions associated with the failure of a rock plug at shallow depth (represented by abundant lithics in tephra layer). (2) A paroxysmal phase consisting in a series of large explosions of high intensity $(I=9-10)$ and short duration with a likely Vulcanian style. (3) The transition to an openvent, Strombolian system evidenced by the decrease in explosion energy, increase in juvenile material in tephra fallout, (in particular volcanic glass) and the reduction in VT and LP seismicity.

The 1 February 2014 eruption showed several specificities in comparison with the traditional scheme of events from the 1999-2013 eruptive period, and similarities with the latest eruptions of July 2013 and April 2014:
- The paroxysm was of short duration, high intensity $(I=9-10)$, and preceded by only short pre-eruptive warning.

- While most of the eruptive plumes from the 1999-2015 period dispersed tephra toward the west, the one from the 1 February 2014 paroxysm was directed toward the SSW. This trend, also observed for the eruptions of 1916-1918, February 2008 and March 2016 (SSE) is due to the infrequent secondary wind direction toward the South and needs to be integrated in future tephra fall hazard mitigation studies.

- In terms of PDC hazard, the 1 February 2014 eruption showed that even small volumes of erupted material can produce significant PDCs via flow bulking through material erupted from preceding events on the upper flanks. The ravines that have been stripped by 15 years of eruption further increase hazard, since flows are free to flow down faster and further than they would in a vegetated and naturally dammed ravine.

The eruption can be summarised in two stages. The first is the onset of a striking seismic swarm of VT and LP events, associated with shallow processes of rapid unrest due to the failure of a rock plug (represented by the lithics in tephra layer 2). Petrography suggests the absence of interaction between juvenile andesite magma and host mush in the magma reservoir, in a quick process of ascent, rise in pressure and trigger of the eruption process. This rules out magma mixing 
for this eruption. The second stage is a transition to Strombolian activity, evidenced by the increase in juvenile scoria in tephra fallout. The components of volcanic glass and altered lithics further suggest an open conduit dynamism, supported by the reduction in VT and LP seismicity in favour of harmonic tremors after the paroxysmal phase.

The 1 February 2014 eruption marked the transition from an open-vent dominated activity, with its climax during the Subplinian August 2006 eruption, to a Vulcanian-dominated eruptive behaviour. The short warning preceding the erup- tion, followed by occurrence of PDCs reaching inhabited areas, together with the large amount of fallout erupted and dispersed toward a very infrequent direction, represents a high hazard. This event thus urges for revised hazard mitigation scenarios at Tungurahua and can serve as an example for other volcanoes in crisis.

Data availability. Data are presented in the paper. Any additional meta-data are available upon request. 


\section{Appendix A: Field data}

\section{A1 PDC final lobes}

Table A1. Location of the most distal PDC front deposits.

\begin{tabular}{lrrrrrrrrr}
\hline Ravine & Vascún & Juive Pampa & Juive-Grande & Juive v.-Minero & Hacienda & Achupashal & Achu-West & Romero & Rea \\
\hline North & 0785961 & 0782360 & 0782307 & 0782442 & 0780052 & 0779307 & 0779944 & 0777198 & 0779504 \\
East & 9841782 & 9843861 & 9843030 & 9842270 & 9842785 & 9839171 & 9840256 & 9837637 & 9836248 \\
\hline
\end{tabular}

Northing and easting in metres. Coordinate system: WGS84 - zone South West 1.
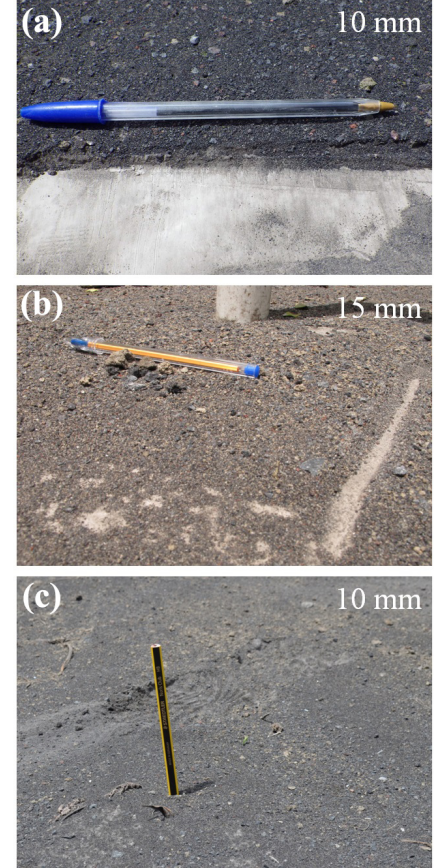

(d)

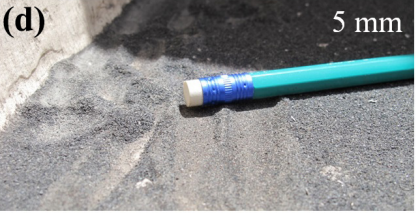

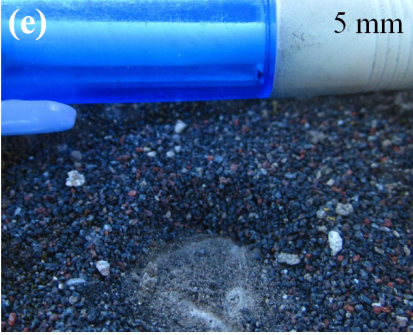
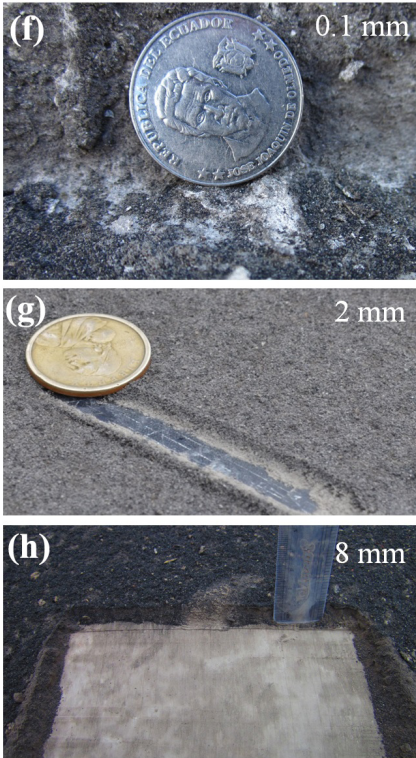
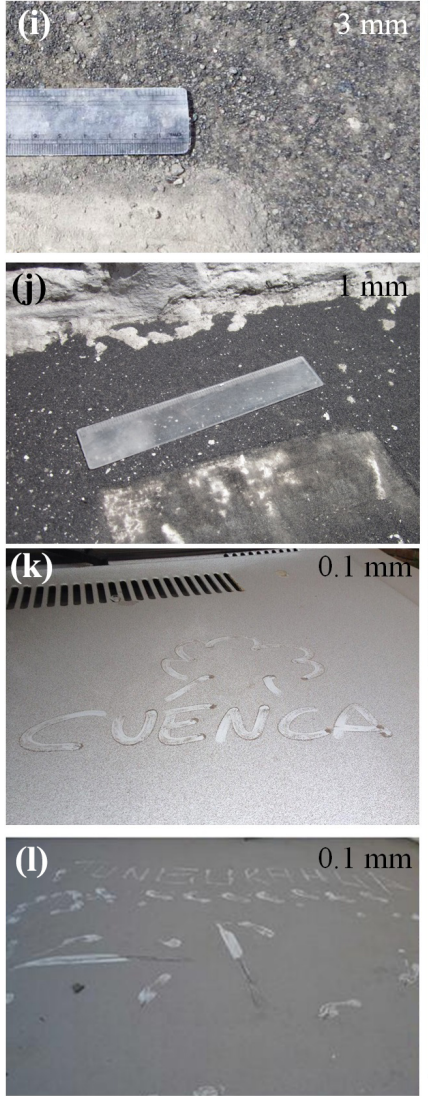
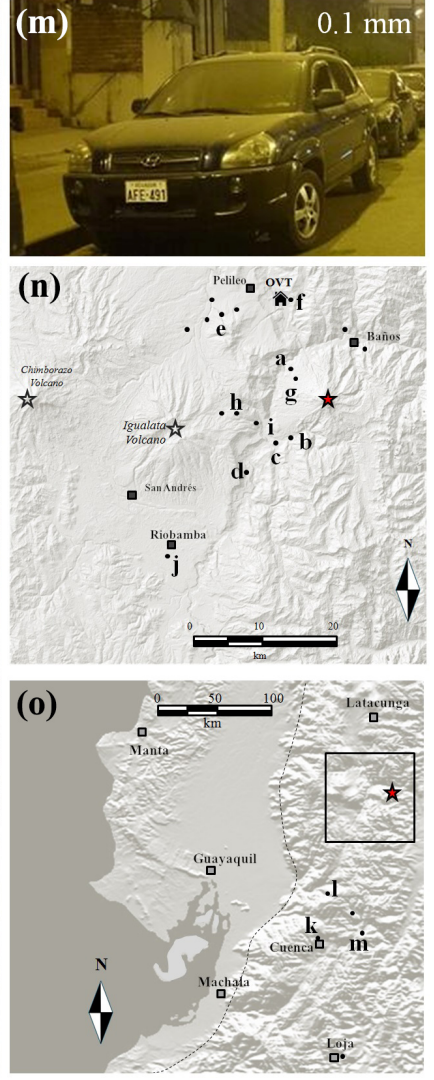

Figure A1. Field observations of the February 2014 tephra fall deposits at proximal (a-i), medial (j) and distal areas (k-m). Distal points were all observed on 1 February, while proximal to medial observations were taken before 14 February. The location of points is reported in the adjunct maps. Labels for point locations are (a) San Juan, (b) Palictahua 1, (c) Palictahua 2 (Ganzhi), (d) Capil, (e) Humbalo, (f) OVT, (g) Bilbao solar panel, (h) Santa fe de Galan, (i) Cahuaji, (j) Riobamba cemetery, (k) Cuenca, (l) Guapan, and (m) Gualaceo. 


\section{A2 Tephra fallout deposit}

Table A2. Volume and mass calculation for the tephra fall deposit. Italics correspond to numerical parameters needed for volume estimates using the different methods. See Appendix B for details.

\begin{tabular}{llrr}
\hline Method & Parameter & Case A & Case B \\
\hline Exponential & number of isopachs & 5 & 4 \\
\hline & mean rel. squared error & 0.0502 & 0.005008 \\
& Segment $1\left(\mathrm{~m}^{3}\right)$ & $4.44 \times 10^{6}$ & $2.80 \times 10^{6}$ \\
& $c 1$ & 0.07367 & 0.02465 \\
& $m 1$ & 0.1734 & 0.1216 \\
& Segment 2 $\left(\mathrm{m}^{3}\right)$ & $5.50 \times 10^{6}$ & $1.75 \times 10^{6}$ \\
& $c 2$ & 0.00273 & 0.00348 \\
& $m 2$ & 0.02915 & 0.0494 \\
\hline \multirow{2}{*}{ Weibull } & number of isopachs & 5 & 4 \\
\hline & mean rel. squared error & 0.02211 & 0.01569 \\
& $\Theta$ & 0.00035 & 0.00392 \\
& $\lambda$ & 98.82 & 22.04 \\
& $\eta$ & 0.2530 & 0.5959 \\
\hline Power law & number of isopachs & 5 & 4 \\
\hline & mean rel. squared error & 0.0233 & 0.0321 \\
& PL coefficient (TPL) & 1.0450 & 0.8167 \\
& PL exponent (m) & 1.9580 & 2.0870 \\
& Estimated proximal limit & 3.8740 & 5.3520 \\
\hline
\end{tabular}

Table A3. Areas $(A)$ enclosed by each isopach of certain thickness $(T)$ and their respective natural logarithm $(\ln (T))$ and square roots $(\operatorname{Sqrt}(A))$, as used for the volume estimates in both A and B scenarios of tephra distribution.

\begin{tabular}{lllll}
\hline Case & $\begin{array}{l}\text { Thickness }(T), \\
\mathrm{m}\end{array}$ & $\begin{array}{l}\ln (T), \\
\mathrm{m}\end{array}$ & $\begin{array}{l}\text { Area, } \\
\mathrm{km}^{2}\end{array}$ & $\begin{array}{l}\operatorname{Sqrt}(A), \\
\mathrm{km}\end{array}$ \\
\hline Case A & 0.03 & -3.51 & 44.30 & 6.66 \\
& 0.01 & -4.61 & 88.93 & 6.43 \\
& 0.005 & -5.30 & 260.00 & 16.12 \\
& 0.001 & -6.91 & 1187.30 & 34.46 \\
& 0.0001 & -9.21 & 127873.00 & 113.46 \\
\hline Case B & 0.01 & -4.61 & 55.00 & 7.42 \\
& 0.005 & -5.30 & 172.00 & 13.11 \\
& 0.001 & -6.91 & 638.00 & 25.26 \\
& 0.0001 & -9.21 & 5165.00 & 71.87 \\
\hline
\end{tabular}

\section{Appendix B: Calculation of erupted parameters}

Table 1 gives the results of calculation following three interpolation methods, with details below and parameters used in Table A2:

- Exponential thinning volume is calculated through the adjunction of the volumes calculated for segments 1 and 2 following the method of Pyle (1989): $V=c \times e^{(-m x)}$.

- The Weibull method used the Weibull function integration (Bonadonna and Costa, 2012): $V=2\left(\left(\Theta \times \lambda^{2}\right) / \eta\right)$.

- The power law is following the approach of Bonadonna and Houghton (2005). TPL and $\mathrm{m}$ are coefficient and exponent of the power law. Here, we used $C=2$ and $B=600$ as both proximal and distal limit of integration: $T(x)=T_{\mathrm{pl}} \times A^{(-0.5 m)} ; V=\left[2 T_{\mathrm{pl}} /(2-m)\right] \times\left[C^{(2-m)}-\right.$ $\left.B^{(2-m)}\right]$. 
Author contributions. JER undertook the fieldwork and laboratory analysis on tephra; GAD carried out the field work on the PDC deposits; SVV performed analysis from thermal imagery and volume estimations for PDCs; JB, LT and PR contributed during the field investigation and discussion of data; and JDA did the petrology of samples.

Competing interests. The authors declare that they have no conflict of interest.

Acknowledgements. The authors acknowledge the Instituto Geofísico (IG-EPN) for providing the necessary laboratory material for a fast analysis of the tephra as well as a field thermometer and assistance during field work by Benjamin Bernard. The thin sections were made by the funding of Universidad de Atacama (Chile) with the support of Jesus Lopez. The careful review of Jean-Luc Le Pennec increased the quality of the manuscript together with the comments of Joan Martí and Setsuya Nakada during an early version review. This study is financially supported by the Deutsche Forschungsgemeinschaft (grant DO1953/1-1) and Baylat CoCotE grants to Guilhem Amin Douillet.

Edited by: Antonella Longo

Reviewed by: Jean-Luc Le Pennec and one anonymous referee

\section{References}

Arellano, S., Hall, M., Samaniego, P., Le Pennec, J.-L., Ruiz, A., Molina, I., and Yepes, H.: Degassing patterns of Tungurahua volcano (Ecuador) during the 1999-2006 eruptive period, inferred from remote spectroscopic measurements of $\mathrm{SO}_{2}$ emissions, J. Volcanol. Geoth. Res., 176, 151-162, 2008.

Bernard, B., Bustillos, J., Wade, B., and Hidalgo, S.: Influence of the wind direction variability on the quantification of tephra fallouts: December 2012 and March 2013 Tungurahua eruptions, Avances, 5, A14-A21, 2013.

Bernard, J., Kelfoun, K., Le Pennec, J.-L., and Vargas, S. V.: Pyroclastic flow erosion and bulking processes: comparing fieldbased vs. modeling results at Tungurahua volcano, Ecuador, B. Volcanol., 76, 1-16, 2014.

Bernard, J., Eychenne, J., Le Pennec, J.-L., and Narváez, D.: Mass budget partitioning during explosive eruptions: insights from the 2006 paroxysm of Tungurahua volcano, Ecuador, Geochem. Geophy. Geosy., 17, 3224-3240, 2016.

Biass, S., Bagheri, G., Aeberhard, W., and Bonadonna, C.: TError: towards a better quantification of the uncertainty propagated during the characterization of tephra deposits, Statistics in Volcanology, 1, 1-27, 2014.

Blott, S. J. and Pye, K.: GRADISTAT: a grain size distribution and statistics package for the analysis of unconsolidated sediments, Earth Surf. Proc. Land., 26, 1237-1248, 2001.

Bonadonna, C. and Costa, A.: Estimating the volume of tephra deposits: a new simple strategy, Geology, G32769, https://doi.org/10.1130/G32769.1, 2012.

Bonadonna, C. and Houghton, B.: Total grain-size distribution and volume of tephra-fall deposits, B. Volcanol., 67, 441-456, 2005.
Brown, R. J. and Andrews, G.: Deposits Of Pyroclastic Density Currents, in: The encyclopedia of volcanoes, edited by: Sigurdsson, H., Houghton, B., McNutt, S., Rymer, H., and Stix, J., chap. 35, 631-648, Elsevier, Academic Press, San Diego, CA, USA, 2015.

Bustillos, J.: Transition de style éruptif au cours des éruptions andésitiques en système ouvert: apport de l'étude des cendres avec application au volcan Tungurahua (Equateur), MSc. Thesis, Université Nice Sophia Antipolis, Nice, France, 2010.

Bustillos, J., Romero, J., and Guerrero, G.: New field data on the Guagua Pichincha (Ecuador) 900 AD Subplinian eruption and its eruptive parameters, Pyroclastic Flow, 4, 1-4, 2014.

Bustillos, J., Romero, J. E., and Troncoso, L.: Tephra fall at Tungurahua Volcano (Ecuador) - 1999-2014: An Example of Tephra Accumulation from a Long-lasting Eruptive Cycle, Geofís. Int., 55, 55-67, 2016.

Cas, R. and Wright, J.: Volcanic Successions, Modern and Ancient: A Geological Approach to Processes, Products and Successions, 528 pp., Allen \& Unwin, London, UK, Chapman \& Hall, Boston, USA, 1987.

Champenois, J., Pinel, V., Baize, S., Audin, L., Jomard, H., Hooper, A., Alvarado, A., and Yepes, H.: Large-scale inflation of Tungurahua volcano (Ecuador) revealed by Persistent Scatterers SAR interferometry, Geophys. Res. Lett., 41, 5821-5828, 2014.

Cioni, R., Pistolesi, M., and Rosi, M.: Plinian and Subplinian eruptions, in: The encyclopedia of volcanoes, edited by: Sigurdsson, H., Houghton, B., McNutt, S., Rymer, H., and Stix, J., chap. 29, 519-536, Elsevier, Academic Press, San Diego, CA, USA, 2015.

Clarke, A., Ongaro, T., and Belousov, A.: Vulcanian eruptions, in: The encyclopedia of volcanoes, edited by: Sigurdsson, H., Houghton, B., McNutt, S., Rymer, H., and Stix, J., S., chap. 28, 505-518, Elsevier, Academic Press, San Diego, CA, USA, 2015.

Cole, P., Stinton, A., Odbert, H., Bonadonna, C., and Stewart, R.: An inclined Vulcanian explosion and associated products, J. Geol. Soc., 172, 287-293, 2015.

Crowe, B. M. and Fisher, R. V.: Sedimentary structures in basesurge deposits with special reference to cross-bedding, Ubehebe Craters, Death Valley, California, Geol. Soc. Am. Bull., 84, 663682, 1973.

Douillet, G. A., Pacheco, D. A., Kueppers, U., Letort, J., Tsang-HinSun, È., Bustillos, J., Hall, M., Ramón, P., and Dingwell, D. B.: Dune bedforms produced by dilute pyroclastic density currents from the August 2006 eruption of Tungurahua volcano, Ecuador, B. Volcanol., 75, 1-20, 2013a.

Douillet, G. A., Tsang-Hin-Sun, È., Kueppers, U., Letort, J., Pacheco, D. A., Goldstein, F., Von Aulock, F., Lavallée, Y., Hanson, J. B., Bustillos, J., Robin, C., Ramón, P., Hall, M., and Dingwell, D. B.: Sedimentology and geomorphology of the deposits from the August 2006 pyroclastic density currents at Tungurahua volcano, Ecuador, B. Volcanol., 75, 1-21, 2013 b.

Engwell, S., Sparks, R., and Aspinall, W.: Quantifying uncertainties in the measurement of tephra fall thickness, J. Appl. Volcanol., 2, 5, https://doi.org/10.1186/2191-5040-2-5, 2013.

Eychenne, J., Le Pennec, J.-L., Troncoso, L., Gouhier, M., and Nedelec, J.-M.: Causes and consequences of bimodal grain-size distribution of tephra fall deposited during the August 2006 Tungurahua eruption (Ecuador), B. Volcanol., 74, 187-205, 2012.

Eychenne, J., Le Pennec, J.-L., Ramón, P., and Yepes, H.: Dynamics of explosive paroxysms at open-vent andesitic systems: high- 
resolution mass distribution analyses of the 2006 Tungurahua fall deposit (Ecuador), Earth Planet. Sci. Lett., 361, 343-355, 2013.

Fierstein, J. and Nathenson, M.: Another look at the calculation of fallout tephra volumes, B. Volcanol., 54, 156-167, 1992.

Folk, R. L. and Ward, W. C.: Brazos River bar: a study in the significance of grain size parameters, J. Sediment. Res., 27, 3-26, 1957.

Hall, M. L., Robin, C., Beate, B., Mothes, P., and Monzier, M.: Tungurahua Volcano, Ecuador: structure, eruptive history and hazards, J. Volcanol. Geoth. Res., 91, 1-21, 1999.

Hall, M. L., Steele, A. L., Mothes, P. A., and Ruiz, M. C.: Pyroclastic density currents (PDC) of the 16-17 August 2006 eruptions of Tungurahua volcano, Ecuador: Geophysical registry and characteristics, J. Volcanol. Geoth. Res., 265, 78-93, 2013.

Hall, M. L., Steele, A. L., Bernard, B., Mothes, P. A., Vallejo, S. X., Douillet, G. A., Ramón, P. A., Aguaiza, S. X., and Ruiz, M. C.: Sequential plug formation, disintegration by Vulcanian explosions, and the generation of granular Pyroclastic Density Currents at Tungurahua volcano (2013-2014), Ecuador, J. Volcanol. Geoth. Res., 306, 90-103, 2015.

Hidalgo, S., Battaglia, J., Arellano, S., Steele, A., Bernard, B., Bourquin, J., Galle, B., Arrais, S., and Vásconez, F.: $\mathrm{SO}_{2}$ degassing at Tungurahua volcano (Ecuador) between 2007 and 2013: transition from continuous to episodic activity, J. Volcanol. Geoth. Res., 298, 1-14, 2015.

Inman, D. L.: Measures for describing the size distribution of sediments, J. Sediment. Res., 22, 125-145, 1952.

Instituto Geofísico, E. P. N.: Informe especial del volcán Tungurahua no. 01, available at: http://www.igepn.edu.ec/, last access: 9 February 2014a.

Instituto Geofísico, E. P. N.: Informe especial del volcán Tungurahua no. 02, available at: http://www.igepn.edu.ec/, last access: 9 February 2014 b.

Instituto Geofísico, E. P. N.: Informe especial del volcán Tungurahua no. 04, available at: http://www.igepn.edu.ec/, last access: 9 February $2014 \mathrm{c}$.

Instituto Geofísico, E. P. N.: Informe especial del volcán Tungurahua no. 05, http://www.igepn.edu.ec/, last access: 9 February 2014d.

Jaya, D.: El colapso del volcán Tungurahua en el Holoceno Superior: Análisis de estabilidad y dinamismos explosivos asociados, $\mathrm{PhD}$ thesis, Tesis de grado, Escuela Politecnica Nacional, Quito, Ecuador, 2004.

Kelfoun, K., Samaniego, P., Palacios, P., and Barba, D.: Testing the suitability of frictional behaviour for pyroclastic flow simulation by comparison with a well-constrained eruption at Tungurahua volcano (Ecuador), B. Volcanol., 71, 1057-1075, 2009.

Klawonn, M., Houghton, B. F., Swanson, D. A., Fagents, S. A., Wessel, P., and Wolfe, C. J.: From field data to volumes: constraining uncertainties in pyroclastic eruption parameters, B. Volcanol., 76, 1-16, 2014.

Le Maitre, R., Bateman, P., Dudek, A., Keller, J., Lameyre, L., Sabine, P., Schmid, R., Sorensen, H., Streckeisen, A., Wooley, A., and Zanettin, B.: A classification of igneous rocks and glossary of terms, Recommendations of the IUGS Commission on the Systematics of Igneous Rocks, Blackwell Scientific Publications, Oxford, UK, 1989.

Le Pennec, J.-L., Jaya, D., Samaniego, P., Ramón, P., Yánez, S. M., Egred, J., and Van Der Plicht, J.: The AD 1300-1700 eruptive pe- riods at Tungurahua volcano, Ecuador, revealed by historical narratives, stratigraphy and radiocarbon dating, J. Volcanol. Geoth. Res., 176, 70-81, 2008.

Le Pennec, J.-L., Ruiz, G. A., Ramón, P., Palacios, E., Mothes, P., and Yepes, H.: Impact of tephra falls on Andean communities: The influences of eruption size and weather conditions during the 1999-2001 activity of Tungurahua volcano, Ecuador, J. Volcanol. Geoth. Res., 217, 91-103, 2012.

Maeno, F., Nakada, S., Nagai, M., and Kozono, T.: Ballistic ejecta and eruption condition of the vulcanian explosion of Shinmoedake volcano, Kyushu, Japan on 1 February, 2011, Earth Planets Space, 65, 609-621, 2013.

Morrissey, M. and Mastin, L.: Vulcanian eruptions, in: The encyclopedia of volcanoes, edited by: Sigurdsson, H., Houghton, B., McNutt, S., Rymer, H., and Stix, J., 463-475, Elsevier, Academic Press, San Diego, CA, USA, 2000.

Murcia, H. F., Borrero, C. A., Pardo, N., Alvarado, G. E., Arnosio, M., and Scolamacchia, T.: Depósitos volcaniclásticos: Términos y conceptos para una clasificación en español, Revista Geológica de América Central, 48, 15-39, 2013.

Myers, M. L., Geist, D. J., Rowe, M. C., Harpp, K. S., Wallace, P. J., and Dufek, J.: Replenishment of volatile-rich mafic magma into a degassed chamber drives mixing and eruption of Tungurahua volcano, B. Volcanol., 76, 1-17, 2014.

Newhall, C. G. and Self, S.: The volcanic explosivity index (VEI) an estimate of explosive magnitude for historical volcanism, J. Geophys. Res.-Oceans, 87, 1231-1238, 1982.

Otto, G. H.: A modified logarithmic probability graph for the interpretation of mechanical analyses of sediments, J. Sediment. Res., 9, 62-76, https://doi.org/10.1306/D4269044-2B26-11D78648000102C1865D, 1939.

Palma, J.: Wind Reanalysis, available at: https://vhub.org/resources/ windre (last access: 30 June 2015), 2013.

Parra, R., Bernard, B., Narváez, D., Le Pennec, J.-L., Hasselle, N., and Folch, A.: Eruption Source Parameters for forecasting ash dispersion and deposition from vulcanian eruptions at Tungurahua volcano: Insights from field data from the July 2013 eruption, . Volcanol. Geoth. Res., 309, 1-13, 2016.

Polacci, M.: Constraining the dynamics of volcanic eruptions by characterization of pumice textures, Ann. Geophys.-Italy, 48, 731-738, https://doi.org/10.4401/ag-3229, 2005.

Pyle, D. M.: The thickness, volume and grainsize of tephra fall deposits, B. Volcanol., 51, 1-15, 1989.

Pyle, D. M.: Sizes of volcanic eruptions, Encyclopedia of Volcanoes, 1, 263-269, 2000.

Pyle, D. M.: Assessment of the minimum volume of tephra fall deposits, J. Volcanol. Geoth. Res., 69, 379-382, 1995.

Rose, W., Self, S., Murrow, P., Bonadonna, C., Durant, A., and Ernst, G.: Nature and significance of small volume fall deposits at composite volcanoes: Insights from the October 14, 1974 Fuego eruption, Guatemala, B. Volcanol., 70, 1043-1067, 2008.

Samaniego, P., Le Pennec, J., Barba, D., Hall, M., Robin, C., Mothes, P., Yepes, H., Troncoso, L., and Jaya, D.: Mapa de los peligros potenciales del volcán Tungurahua, Escale 1:50.000, 3rd version, Departamento de Geofísica de la Escuela Politécnica de Ecuador, Quito, Ecuador, 2008.

Samaniego, P., Le Pennec, J.-L., Robin, C., and Hidalgo, S.: Petrological analysis of the pre-eruptive magmatic process prior to the 
2006 explosive eruptions at Tungurahua volcano (Ecuador), J. Volcanol. Geoth. Res., 199, 69-84, 2011.

Shand, S. J.: Eruptive Rocks: Their Genesis, Composition, Classification, and Their Relation to Ore Deposits, with a Chapter on Meteorites, J. Geol., 56, 593-593, 1948.

Sparks, R. S. J., Bursik, M., Carey, S., Gilbert, J., Glaze, L., Sigurdsson, H., and Woods, A.: Volcanic plumes, Wiley, Chichester, UK, 1997.

Steffke, A. M., Fee, D., Garces, M., and Harris, A.: Eruption chronologies, plume heights and eruption styles at Tungurahua Volcano: Integrating remote sensing techniques and infrasound, J. Volcanol. Geoth. Res., 193, 143-160, 2010.

Troncoso, L., Le Pennec, J.-L., Jaya, D., Vallée, A., Mothes, P., and Arrais, S.: Depósitos de caída de ceniza producidos durante las erupciones del volcán Tungurahua, 14 de julio y 16 de agosto de 2006, in: Abstract book, 6tas Jornadas en Ciencias de la Tierra of the Escuela Politécnica Nacional, Escuela Politécnica Nacional, Quito, Ecuador, 2006.
Vallejo, S., Naranjo, F., Ramón, P., Yépez, H., Hidalgo, S., Anzieta, J., Bernard, B., Narváez, D., Mothes, P., and Douillet, G.: The vulcanian eruption of February 1st, 2014 at Tungurahua Volcano, Ecuador, in: Abstract book, Cities on Volcanoes 8, International Association of Volcanology and Chemistry of the Earth's Interior, Jogjakarta, Indonesia, 2014.

Walker, G. P.: Grain-size characteristics of pyroclastic deposits, J. Geol., 69, 696-714, 1971.

Wright, H. M., Cashman, K. V., Rosi, M., and Cioni, R.: Breadcrust bombs as indicators of Vulcanian eruption dynamics at Guagua Pichincha volcano, Ecuador, B. Volcanol., 69, 281-300, 2007.

Zobin, V. M., Carrasco-Núñez, G., and Vargas-Gutiérrez, V. R.: Field and seismic evaluation of the block-and-ash flows emplaced from eruption columns of the 2005 Vulcanian explosions at Volcán de Colima, Mexico, B. Volcanol., 78, 1-9, 2016. 